\title{
Revisión / Review \\ Bacopa monnieri: Historical aspects to promising pharmacological actions for the treatment of central nervous system diseases
}

\author{
[Bacopa monnieri: Aspectos históricos de las acciones farmacológicas prometedoras para el tratamiento de \\ enfermedades del sistema nervioso central]
}

\author{
Andreia Fuentes Santos ${ }^{1}$, Marília Moraes Queiroz Souza ${ }^{2}$, Karoline Bach Pauli ${ }^{3}$, \\ Gustavo Ratti da Silva ${ }^{1}$, Midia Wolff Marques ${ }^{4}$, Pablo Alvarez Auth ${ }^{1}$, Wanessa de Campos Bortolucci ${ }^{5}$, \\ Zilda Cristiani Gazim ${ }^{5}$, Giani Andrea Linde ${ }^{6}$, Nelson Barros Colauto ${ }^{6}$, \\ Evellyn Claudia Wietzikoski Lovato ${ }^{2} \&$ Francislaine Aparecida dos Reis Lívero ${ }^{7}$
}

\footnotetext{
${ }^{1}$ Graduate Program in Animal Science with Emphasis on Bioactive Products, Universidade Paranaense, Umuarama, Brazil

${ }^{2}$ Graduate Program in Medicinal Plants and Phytotherapeutics in Basic Attention, Paranaense University, Umuarama, Brazil

${ }^{3}$ Federal University of Integração Latino-Americana, Foz do Iguaçu, Brazil

${ }^{4}$ Specialization in Trauma-Orthopedic and Sports Physiotherapy, Paranaense University, Paraná, Brazil

${ }^{5}$ Graduate Program in Biotechnology Applied to Agriculture, Graduate in Animal Science with Emphasis on Bioactive Products, Universidade Paranaense, Umuarama, Brazil

${ }^{6}$ Federal University of Bahia, Salvador, Brazil

${ }^{7}$ Graduate Program in Medicinal Plants and Phytotherapeutics in Basic Attention, Graduate in Animal Science with Emphasis on Bioactive Products, Graduate Program in Biotechnology Applied to Agriculture, Paranaense University, Umuarama, Brazil
}

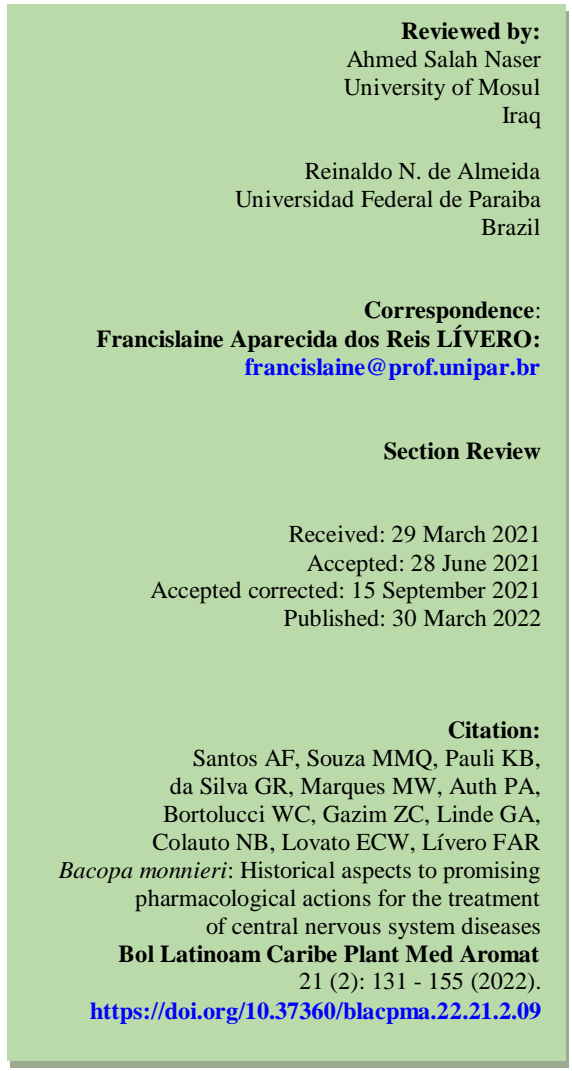

Abstract: Bacopa monnieri (L.) Wettst. (Plantaginaceae), also known as Brahmi, has been used to improve cognitive processes and intellectual functions that are related to the preservation of memory. The objective of this research is to review the ethnobotanical applications, phytochemical composition, toxicity and activity of $B$. monnieri in the central nervous system. It reviewed articles on B. monnieri using Google Scholar, SciELO, Science Direct, Lilacs, Medline, and PubMed. Saponins are the main compounds in extracts of B. monnieri. Pharmacological studies showed that B. monnieri improves learning and memory and presents biological effects against Alzheimer's disease, Parkinson's disease, epilepsy, and schizophrenia. No preclinical acute toxicity was reported. However, gastrointestinal side effects were reported in some healthy elderly individuals. Most studies with $B$. monnieri have been preclinical evaluations of cellular mechanisms in the central nervous system and further translational clinical research needs to be performed to evaluate the safety and efficacy of the plant.

Keywords: Alzheimer; Bacopa monnieri; Epilepsy; Parkinson; Schizophrenia.

Resumen: Bacopa monnieri (L.) Wettst. (Plantaginaceae), también conocida como Brahmi, se ha utilizado para mejorar los procesos cognitivos y las funciones intelectuales que están relacionadas con la preservación de la memoria. El objetivo de esta investigación es revisar las aplicaciones etnobotánicas, composición fitoquímica, toxicidad y actividad de $B$. monnieri en el sistema nervioso central. Se revisaron artículos sobre B. monnieri utilizando Google Scholar, SciELO, Science Direct, Lilacs, Medline y PubMed. Las saponinas son los principales compuestos de los extractos de B. monnieri. Los estudios farmacológicos mostraron que B. monnieri mejora el aprendizaje y la memoria y presenta efectos biológicos contra la enfermedad de Alzheimer, la enfermedad de Parkinson, la epilepsia y la esquizofrenia. No se informó toxicidad aguda preclínica. Sin embargo, se informaron efectos secundarios gastrointestinales en algunos ancianos sanos. La mayoría de los estudios con B. monnieri han sido evaluaciones preclínicas de los mecanismos celulares en el sistema nervioso central y es necesario realizar más investigaciones clínicas traslacionales para evaluar la seguridad y eficacia de la planta.

Palabras clave: Alzheimer; Bacopa monnieri; Epilepsia; Parkinson; Esquizofrenia. 


\section{LIST OF ABBREVIATIONS}

COMT: catechol- $O$-methyltransferase

PEP: prolyl endopeptidase

PARP: poly (ADP-ribose) polymerase

5-HT: 5-hydroxytryptamine (serotonin)

PARP: poly (ADP-ribose) polymerase

T2VO: transient two-vessel occlusion

PKC: protein kinase $\mathrm{C}$

PI3K/AKT: phosphoinositide-3-kinase-protein kinase

BDNF: brain-derived neurotrophic factor

cAMP: cyclic adenosine monophosphate

CREB: cAMP response element binding protein

AChE: acetylcholinesterase

PSAPP: amyloid-peptide overproducing transgenic mouse model

IL-6: interleukin-6

TNF- $\alpha$ : tumor necrosis factor $\alpha$

MCP-1: monocyte chemoattractant protein-1

COX-2: cyclooxygenase-2

iNOS: inducible nitric oxide synthase

MAPK: mitogen-activated protein kinase

6-OHDA: 6-hydroxydopamine

PINK1: melanogaster transgenic model

MPTP: 1-methyl-4-phenyl-1,2,3,6-tetrahydropyridine

Bcl-2: B-cell lymphoma-2

GABA: $\gamma$-aminobutyric acid

mGIuR8: metabotropic glutamate receptor 8

NMDA: $N$-methyl-D-asparate

VGLUT: vesicular glutamate transporter

\section{INTRODUCTION}

In the 1950s, 250 million people worldwide were older than 60 years of age (WHO, 2011). In 2015, this number nearly quadrupled to 901 million (12\% of the world's population). In 2050, the global elderly population is projected to reach 2.1 billion (22\% of the world's population) (WHO, 2011). Aging is associated with declines in memory and cognitive skills, with a concomitant increase in the incidence of aging-related neurodegenerative diseases (Murman, 2015; Castelli et al., 2019; Gentile et al., 2021). In fact, cognitive function refers to multiple mental abilities, including motor function, attention, language, memory, executive control, vision, emotion, sensory function, and consciousness. Furthermore, cognitive impairment is a common characteristic of several diseases, such as Alzheimer's disease, Parkinson's disease, epilepsy, and schizophrenia (Kean et al., 2016).

Alzheimer's disease, a chronic and neurodegenerative disease, has the highest incidence among neurodegenerative diseases, followed by
Parkinson's disease and is associated with aging. It is a progressive and fatal neurodegenerative disorder that is characterized by the massive loss of neural cells and manifested by cognitive impairment, progressively worse psychological and behavioral manifestations, neurological signs, a decline in dailyliving activities, and various neuropsychiatric and behavioral symptoms (Alzheimer's Association, 2016; Apostolova, 2016). The disease is characterized by the progressive atrophy of brain areas that are responsible for cognitive function, such as the cerebral cortex, entorhinal cortex, hippocampus, and ventral striatum. Brain lesions that are caused by the disease produce histopathological characteristics in the cerebral parenchyma, including amyloid fibrillary deposits in the walls of blood vessels that are associated with senile plaques, the accumulation of abnormal filaments of tau protein, the activation of glia, and inflammation (Kumar \& Ekavali, 2015; Alzheimer's Association, 2016).

Parkinson's disease is a chronic and progressive disorder of the central nervous system that results from the loss of dopaminergic neurons in the substantia nigra, with consequent dopamine depletion (Balestrino \& Schapira, 2020). These neurons have cell bodies in the substantia nigra pars compacta and send axons to the nuclei of the base. As the disease progresses and neurons degenerate, they develop cytoplasmic bodies (Lewy bodies) that arise from the deposition of $\alpha$-synuclein anomalous protein (Schrag \& Schott, 2006). The disease is characterized by cardinal signs of stiffness, bradykinesia, postural instability, and tremor. In addition to motor symptoms, sleep disorders, cognitive dysfunction, and depression may also occur, resulting in poor quality of life and making the disease even more disabling with a shortened life expectancy (Mhyre et al., 2012). Complex interactions between genetic, environmental, and pathological factors that involve mitochondrial dysfunction, oxidative stress, inflammation, and excitotoxicity result in Parkinson's disease. In the 1960s, the first successful treatment emerged, paving the way for the development of new effective therapies. The introduction of levodopa represented the greatest therapeutic breakthrough in Parkinson's disease treatment, which produced clinical benefits for virtually all patients and reduced mortality. However, soon after levodopa was introduced, it became apparent that long-term treatment was complicated by the development of adverse effects, including motor fluctuations, dyskinesias, and 
neuropsychiatric complications. Additionally, as the disease progresses, patients experience manifestations that do not respond adequately to levodopa treatment, such as episodes of freezing, postural instability, autonomic dysfunction, and dementia. Thus, the search is ongoing for new drugs and safe and effective adjuvants that are capable of acting on dopaminergic, cognitive, and motor alterations (Lang, 2009; Olanow et al., 2009; Armstrong \& Okun, 2020).

Other nervous system conditions beyond neurodegenerative diseases, such as epilepsy and schizophrenia, significantly impair patients' quality of life. Epilepsy is a neurological disease that can be prevented and controlled in up to $70 \%$ of patients (Thijs et al., 2019; Beghi, 2020). Failure to treat is a risk factor for sudden death and trauma. The causes of epilepsy are either genetic or acquired. Acquired causes comprise the vast majority of cases and include head trauma, perinatal injury, and brain infections, including neurocysticercosis and stroke. In some cases, the cause is unknown. Epileptic seizures that are caused by transient changes in neuronal activity may manifest in different ways, but the common form is seizure (WHO, 2005; Stafstrom \& Carmant, 2015). This clinical condition is produced by a sudden, abnormal, and disordered electrical discharge of neurons that can manifest as focal seizures when restricted in regions bordering on the brain or generalized seizures when discharges originate within the brain and are distributed bilaterally. Such seizures may or may not cause the loss of consciousness (Sokhi et al., 2016). These imbalances are related to the depolarization of excitatory neurons that activate nearby inhibitory interneurons that suppress the activity of stimulated cells and adjacent neurons, where neurotransmitters are involved in the inhibition process, such as glycine, glutamate and $\gamma$-aminobutyric acid (GABA), the main neurotransmitter inhibitory effects of the brain (Valenzuela et al., 2011). Treatment of epilepsy are generally due with monotherapy (i.e., benzodiazepinics) and although each treatment has its own unique adverse effect profile, central effects are prominent and can affect quality of life (Liu et al., 2017a).

Schizophrenia is one of the most serious and challenging psychiatric disorders. It is defined as a complex clinical syndrome that consists of various psychopathological manifestations that involve thought, perception, emotion, movement, and behavior. It is very prevalent among psychiatric conditions without pathognomonic symptoms but with distortions of thought and perception, and a dulling of affect without impairments in intellectual capacity. Over time, however, cognitive impairment may appear (Vannorsdall \& Schretlen, 2019). Limitations that are imposed by the disease result from the deterioration of various mental processes that causes positive and negative symptoms. Positive symptoms are additional behaviors that occur during times of psychiatric crisis, such as delusions, hallucinations, changes in speech, and behavioral alterations (e.g., catatonia and movement disorders). Negative symptoms consist of a loss of function, characterized by lower motor and psychic activity, flat affect, and anhedonia (Khan et al., 2013). The course of schizophrenia is variable. Approximately $30 \%$ of cases have complete or almost complete recovery. Approximately $30 \%$ of cases experience incomplete remission or partial functional impairment, and approximately $30 \%$ of cases exhibit significant and persistent impairments in professional, social, and affective function (Lambert et al., 2010). The most common medications for treating schizophrenia are risperidone, olanzapine, and quetiapine. However, psychiatrists currently need 4-6 weeks to determine the efficacy of these drugs, thus possibly delaying adequate treatment (Tandon $e t$ $a l ., 2008)$. Drugs that are used to treat schizophrenia can cause serious side effects, including movement disorders, weight gain, and metabolic dysfunction (Leucht et al., 2013).

Since above mentioned, therapeutic alternatives for these diseases are quite limited. Although effective in some cases, the available drugs act only in a palliative manner and have many side effects, thus making the search and development of new drugs extremely necessary (Khan et al., 2013; DeMaagd \& Philip, 2015; Stafstrom \& Carmant, 2015; Apostolova, 2016). Therefore, new pharmacological targets and therapeutic agents, including medicinal plants, are a potential alternative to treat these pathophysiologies.

Several plants have been studied with regard to their memory properties. Bacopa monnieri (L.) Wettst. (Family Plantaginaceae) has several notable biological activities that are related to memory, brain function, and intellectual capacity. B. monnieri extracts have been used for neurological treatment to improve concentration, control impulsivity, and exert calming actions, among other benefits (Ahn et al., 2016). Preclinical and clinical studies that have sought to improve the cognition-enhancing effects of 
B. monnieri extracts have reported promising results (Gohil \& Patel, 2010). Clinical studies reported positive effects on memory formation, learning, attention, concentration, and adaptation to environmental stressful situations that affect cognition (Aguiar \& Borowski, 2013). Extracts of $B$. monnieri have also been used to treat digestive complaints and skin disorders, and antiepileptic, antipyretic, and analgesic effects have also been observed (Bammidi et al., 2011).

Thus, considering the importance of $B$. monnieri, this review discusses the ethnobotanical applications, phytochemical composition, and activity of this species in the central nervous system, with a focus on cognitive performance, epilepsy, schizophrenia, Alzheimer's disease, and Parkinson's disease. Studies that evaluated the safety of $B$. monnieri are also discussed.

\section{MATERIALS AND METHODS}

It was reviewed articles on Bacopa monnieri that were published from January 1991 to August 2020 using online journals and books that were published in English, Portuguese, and Spanish. The bibliographic survey was performed using Google Scholar, SciELO, Science Direct, Lilacs, Medline, and PubMed. The data that have been published on this species consist of its history, ethnobotany, ethnopharmacology, phytochemistry, pharmacology, and toxicity. We used the following keywords in our search: $\quad B$ monnieri, ethnobotany, ethnopharmacology, chemical composition, pharmacological action, and toxicity.

\section{History, organoleptic characteristics, and ethnobotanical uses of Bacopa monnieri}

Bacopa monnieri (L.) Pennell is also referred to as the "herb of grace," "Brahmi," "Aindri" and "Hissopo of water". It is a creeping perennial plant with a small stature. Its scientific name has several synonyms, including Anisocalyx limnanthiflorus Hance, Bacopa monnieri (L.) Hayata \& Matsum., Bacopa monnieri (L.) Wettst., Bramia indica Lam., Bramia monniera (L.) Drake, Bramia monnieri (L.) Pennell, Calytriplex obovata Ruiz \& Pav., Capraria monnieri (L.) Roxb., Gratiola monnieri (L.) L., Gratiola parviflora Willd. ex Schltdl. \& Cham., Gratiola portulacacea Weinm., Gratiola tetrandra Stokes, Habershamia cuneifolia (Michaux) Raf., Herpestis africana Steud., Herpestis brownei Steud.,
Herpestis calytriplex Steud., Herpestis cuneifolia Pursh, Herpestis monnieri (L.) Rothm., Herpestis monnieria (L.) Humb., Herpestis monnieria (L.) Kunth, Herpestis moranensis Kunth, Herpestis pedunculosa Steud., Herpestis procumbens Hort. Berol. ex Spreng., Herpestis spathulata Bl., Hydrotrida beccabunga Willd., Limosella calycina Forsk., Lysimachia monnieri L., Monniera africana Persoon, Monniera brownei Persoon, Monniera cuneifolia Michx., Monniera monniera (L.) Britton, and Monniera pedunculosa Persoon (Hassler, 2018). It has a wide geographical distribution. In India and the tropics, it grows naturally in moist soils, shallow water, and marshes. It is easily cultivated. It produces fruits and pale blue or white flowers in summer. Each part of the plant has organoleptic characteristics such as color, odor, taste, and consistency (Figure No. 1).

$B$. monnieri is an adaptogenic plant that is used in Ayurvedic medicine. B. monnieri was named after Lord Brahma, the creator of the mythology of a world that is surrounded by medicinal plants and the originator of the science of Ayurveda. It is an important plant in India that has been used in religious, social, and medical practices since the Vedic civilization. Its antiquity can be traced back to the time of Athar Ved (the science of well-being) that was written in $800 \mathrm{BC}$, which mentioned this plant in the first verse of the third chapter of Athar Samhita (compilation on factors that promote well-being) (Kean et al., 2015).

All parts of B. monnieri have been used for medicinal purposes. It has been reported to have antiepileptic, antidepressant, anxiolytic, gastrointestinal, muscular, cardiovascular, and antitumor effects (Bammidi et al., 2011; Aguiar \& Borowski, 2013). The oral use of B. monnieri leaves for the treatment of epileptic seizures is widespread in India as a decoction, juice, and powder, and it is used as an infusion in Egyptian communities (Shanmugasundaram et al., 1991; Poonam \& Singh, 2009; Sharma et al., 2013; Silambarasan \& Ayyanar, 2015; Emilie et al., 2019). In the Himalayas in Nepal, juice of the entire plant is given orally as a diuretic, cardiac tonic, memory enhancer, and hair tonic (Singh et al., 2012). Its antioxidant actions are notable (Mukherjee et al. 2011; Shinomol et al., 2012), with neuroprotective actions that increase cognitive and motor performance (Uabundit et al., 2010; Saini et al., 2012; Aguiar \& Borowski, 2013). 


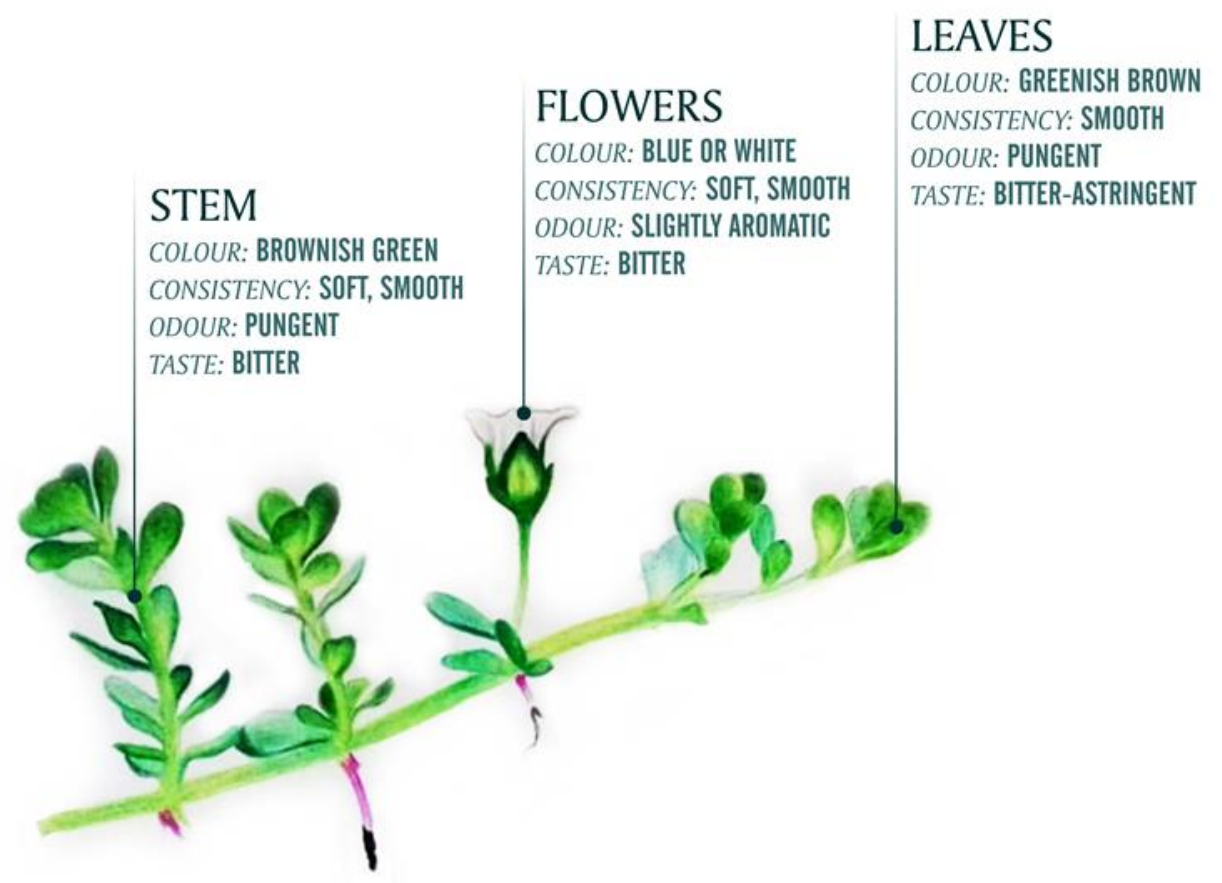

Figure No. 1

Bacopa monnieri and its organoleptic characteristics
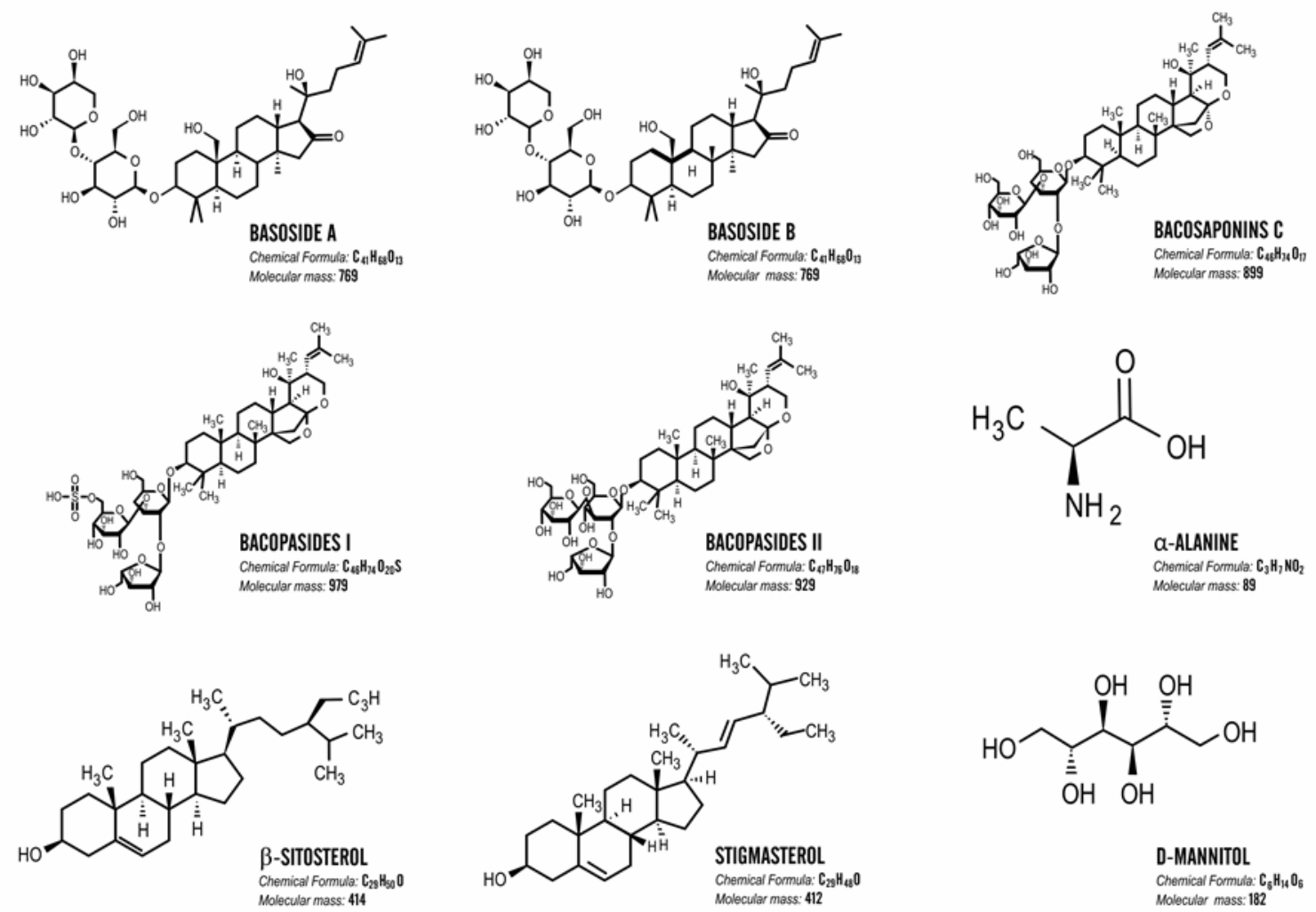

Figure No. 2

Main chemical constituents of Bacopa monnieri

Boletín Latinoamericano y del Caribe de Plantas Medicinales y Aromáticas / 135 


\section{Main bioactive constituents of Bacopa monnieri}

The chemical constituents of Bacopa monnieri have been identified in its stems, leaves, flowers, fruits, and roots. Its bioactive metabolites are mainly concentrated in the stems and leaves. The main bioactive constituents of B. monnieri (Figure No. 2) are tetracyclic triterpene saponins (jujubogenin and pseudojujubagenin), bacoside- $\mathrm{A}$ and -B (including bacoside-A1 and -A3), bacopasaponin-A, -B, -C, -D, $-\mathrm{E}$, and $-\mathrm{F}$, alkaloids (herpestine, brahmin, and nicotinin), flavonoids (luteolin-7 glucoside, glucuronyl-7-apigenin, glucortonyl-7-luteolin, and common phytosterols), D-mannitol, glutamic acid, glycoside, stigmasterol, $\alpha$-alanine, $\beta$-sitosterol, cucurbitacin-B, cucurbitacin-E, bittulinic acid, bacobitacin-A, -B, -C, and -D, cucurbitacin-E, monnieraside-I and -III, and plantioside-B (Deepak \& Amit, 2004; Deepak et al., 2005; Sivaramakrishna et al., 2005; Bhandari et al., 2007; Zhou et al., 2007; Rastogi et al., 2012b; Aguiar \& Borowski, 2013; Jain \& Das, 2016; Mallick et al., 2017). The pharmacological properties of $B$. monnieri are attributed to its high content of active principle bacosides that have high efficacy in the central nervous system (Menon et al., 2010). Among its metabolites, the most studied is bacoside-A, which is found in different concentrations in different parts of the plant (Pandey et al., 2010; Mathew et al., 2010a; Mathew et al., 2010b; Mathew et al., 2011; Rastogi et al., 2012b; Aguiar \& Borowski, 2013).

\section{Pharmacological effects of Bacopa monnieri on the central nervous system}

The pharmacological activity of Bacopa monnieri has been exploited to improve learning and memory and treat depression, emotional stress, fatigue, anxiety, insomnia, Alzheimer's disease, Parkinson's disease, epilepsy, and schizophrenia (Ahn et al., 2016). The effects of B. monnieri on the central nervous system detailed in this review are summarized in Figure No. 3. To explore and summarized the B. monnieri effects on central nervous system and its safety, it was revised 52 articles previously published in scientific literature.

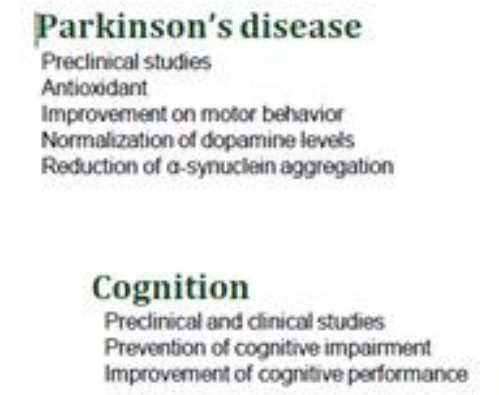

Parkinson's disease Preclinical studies Antioxidant Normelization of dopamine levets Reduction of a-synuclein aggregation Cognition Prevention of cognitive impairment Improvement of cognitive performance

\section{Neuropharmacology of Bacopa monnieri}

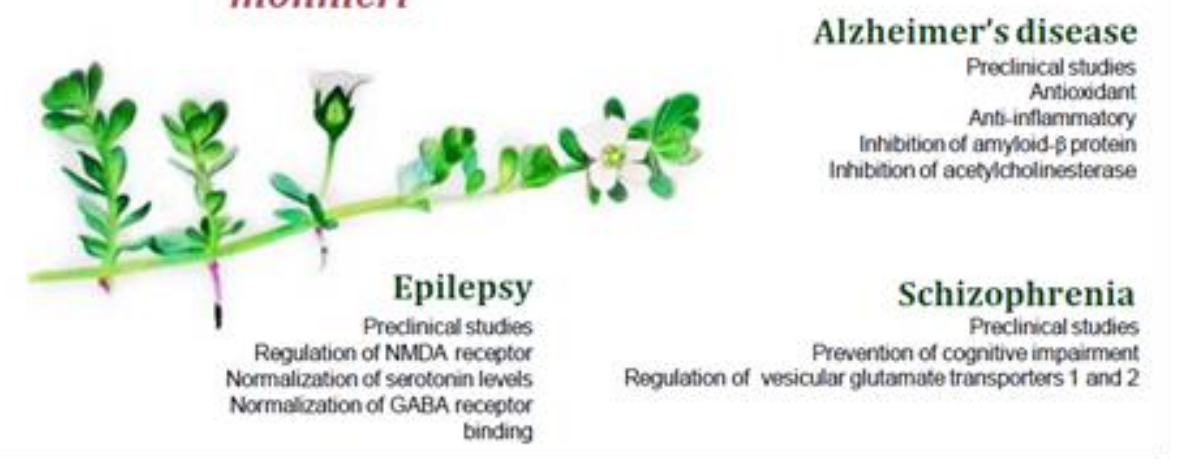

Figure No. 3

\section{Pharmacological effects of Bacopa monnieri on the central nervous system}

\section{Improvement in cognitive performance}

Several in vitro and in vivo studies have investigated the pharmacological properties of $B$. monnieri, reporting neuroprotective effects and improvements in cognitive function (Aguiar \& Borowski, 2013). These effects are attributed to its antioxidant, antiapoptotic, and anti-inflammatory actions (Bhattacharya et al., 2000; Shinomol et al., 2011). Several reviews have highlighted its effects on cognitive function (Shinomol et al., 2011; Pase et al., 2012; Aguiar \& Borowski, 2013, Kongkeaw et al., 2014; Kean et al., 2016; McPhee et al., 2016; Kean et al., 2017; Cicero et al., 2018; Kenedy, 2019; Sukumaran et al., 2019). Table No. 1 shows in vitro and in vivo studies that evaluated the effects of $B$. monnieri on cognitive function.

Dethe et al. (2016), investigated the molecular mechanism by which a standardized extract of $B$. monnieri enhances memory based on a panel of cell-free and receptor-transfected cell assays in vitro. The solvent for the extract was not specified in this study, but $B$. monnieri was shown to inhibit catechol- $O$-methyltransferase (COMT), prolyl endopeptidase (PEP), and poly (ADP-ribose) 
polymerase (PARP) and antagonize serotonin 5hydroxytryptamine- $2 \mathrm{~A} \quad\left(5-\mathrm{HT}_{2 \mathrm{~A}}\right)$ and $5-\mathrm{HT}_{6}$ receptors, which have been shown to be associated with learning and memory deficits and agingassociated memory impairments.

Table No. 1

Effects of Bacopa monnieri on cognitive function

\begin{tabular}{|c|c|c|c|c|c|c|}
\hline $\begin{array}{l}\text { Type of } \\
\text { study }\end{array}$ & Extract & Dose & $\begin{array}{c}\text { Time of } \\
\text { treatment }\end{array}$ & Main effects & $\begin{array}{c}\text { Origin of } \\
\text { study }\end{array}$ & Source \\
\hline $\begin{array}{l}\text { Preclinical } \\
\text { (in vitro) }\end{array}$ & $\begin{array}{c}\text { Standardized } \\
\text { (solvent not specified) }\end{array}$ & $\begin{array}{c}5,10,25, \\
\text { and } 100 \mu \mathrm{g} / \mathrm{ml}\end{array}$ & - & $\begin{array}{c}\text { • Inhibition } \\
\text { of COMT, PEP, } \\
\text { ADP-ribose, and } \\
\text { PARP } \\
\text { - Antagonism of } \\
5-\mathrm{HT}_{2 \mathrm{~A}} \text { and 5- } \\
\mathrm{HT}_{6} \text { receptors }\end{array}$ & India & $\begin{array}{l}\text { (Dethe et } \\
\text { al., 2016) }\end{array}$ \\
\hline $\begin{array}{c}\text { Preclinical } \\
\text { (in vitro } \\
\text { and } \\
\text { in vivo in } \\
\text { T2VO mice) }\end{array}$ & Ethanolic & $50 \mathrm{mg} / \mathrm{kg}$ & $\begin{array}{l}1 \text { week } \\
\text { before } \\
\text { and } 3 \\
\text { days after } \\
\text { surgery }\end{array}$ & $\begin{array}{l}\text { - Prevention of } \\
\text { cognitive deficits } \\
\text { related to cerebral } \\
\text { ischemia } \\
\text { - Amelioration of } \\
\text { T2VO-induced } \\
\text { impairments in } \\
\text { non-spatial short- } \\
\text { term memory } \\
\text { performance in } \\
\text { the object } \\
\text { recognition test } \\
\text { through PKC and } \\
\text { PI3K/Akt } \\
\text { mechanisms }\end{array}$ & Japan & $\begin{array}{l}\text { (Le et al., } \\
\text { 2015) }\end{array}$ \\
\hline $\begin{array}{c}\text { Preclinical } \\
\text { (Swiss mice) }\end{array}$ & Ethanolic & $50 \mathrm{mg} / \mathrm{kg}$ & 2-4 weeks & $\begin{array}{c}\text { - Amelioration of } \\
\text { cognitive } \\
\text { impairments } \\
\text { - Enhancement of } \\
\text { neuroregeneration } \\
\text { in trimethyltin- } \\
\text { treated mice in } \\
\text { object location } \\
\text { test and modified } \\
\text { Y maze test }\end{array}$ & Japan & $\begin{array}{l}\text { (Pham et } \\
\text { al., 2019) }\end{array}$ \\
\hline $\begin{array}{c}\text { Preclinical } \\
\text { (C57BL/6 } \\
\text { mice) }\end{array}$ & $\begin{array}{c}\text { Standardized } \\
\text { (solvent not specified) }\end{array}$ & $200 \mathrm{mg} / \mathrm{kg}$ & 4 weeks & $\begin{array}{c}\text { - Improvement in } \\
\text { memory via } \\
\text { increase in cell } \\
\text { proliferation and } \\
\text { neuroblast } \\
\text { differentiation in } \\
\text { the dentate gyrus }\end{array}$ & Korea & $\begin{array}{l}\text { (Kwon et } \\
\text { al., 2018) }\end{array}$ \\
\hline
\end{tabular}




\begin{tabular}{|c|c|c|c|c|c|c|}
\hline $\begin{array}{c}\text { Preclinical } \\
\text { (neonatal } \\
\text { hypoglycemic } \\
\text { rats) }\end{array}$ & $\begin{array}{c}\text { Aqueous extract and } \\
\text { bacoside-A }\end{array}$ & $\begin{array}{c}50 \text { and } 100 \\
\mathrm{mg} / \mathrm{kg}\end{array}$ & 10 days & $\begin{array}{l}\text { - Improvement in } \\
\text { alterations of } \mathrm{D}_{1} \\
\text { and } \mathrm{D}_{2} \text { receptor } \\
\text { expression, } \\
\text { cAMP signaling, } \\
\text { and oxidative } \\
\text { stress-induced } \\
\text { cell death }\end{array}$ & India & $\begin{array}{l}\text { (Thomas et } \\
\text { al., 2013) }\end{array}$ \\
\hline Clinical & Standardized methanolic & $150 \mathrm{mg}$ & 6 weeks & $\begin{array}{c}\text { - Improvement in } \\
\text { tests of cognitive } \\
\text { function }\end{array}$ & India & $\begin{array}{l}\text { (Kumar et } \\
\text { al., 2016) }\end{array}$ \\
\hline Clinical & Standardized ethanolic & $300 \mathrm{mg} /$ day & 12 weeks & $\begin{array}{l}\text { - Improvement in } \\
\text { verbal learning, } \\
\text { memory } \\
\text { acquisition, and } \\
\text { delayed recall }\end{array}$ & Thailand & $\begin{array}{c}\text { (Piyabhan } \\
\text { \& } \\
\text { Wetchateng, } \\
\text { 2014) }\end{array}$ \\
\hline Clinical & Standardized ethanolic & $\begin{array}{c}300 \text { and } 600 \\
\mathrm{mg} / \text { day }\end{array}$ & 12 weeks & $\begin{array}{l}\text { - Improvements } \\
\text { in attention, } \\
\text { cognitive } \\
\text { processing, and } \\
\text { working memory } \\
\text { partially through } \\
\text { the suppression of } \\
\text { AChE activity }\end{array}$ & Thailand & $\begin{array}{l}\text { (Peth-Nui et } \\
\text { al., 2012) }\end{array}$ \\
\hline Clinical & Standardized methanolic & $300 \mathrm{mg} /$ day & 12 weeks & $\begin{array}{l}\text { - Enhancement of } \\
\text { auditory verbal } \\
\text { learning, delayed } \\
\text { word recall, and } \\
\text { Stroop task } \\
\text { performance }\end{array}$ & USA & $\begin{array}{l}\text { (Calabrese } \\
\text { et al., 2008) }\end{array}$ \\
\hline Clinical & Standardized ethanolic & $\begin{array}{c}160 \text { and } 320 \\
\mathrm{mg} / \text { day }\end{array}$ & 16 weeks & $\begin{array}{l}\text { - Improvements } \\
\text { in hyperactivity, } \\
\text { inattention, } \\
\text { mood, sleep, and } \\
\text { cognition }\end{array}$ & Australia & $\begin{array}{l}\text { (Kean } \text { et al., } \\
\text { 2015) }\end{array}$ \\
\hline
\end{tabular}

The effects of an ethanolic extract of $B$. monnieri that contained $22 \%$ bacoside-A and $11 \%$ bacopaside on cognitive performance were evaluated in vitro and in vivo by Le et al. (2015). In the in vitro experiments, organotypic hippocampal slice cultures were used to evaluate neurophysiological activity in the hippocampus and pathophysiology that is relevant to ischemia. The results suggested that B. monnieri was beneficial for the prevention of cerebral ischemia-related cognitive deficits. In the in vivo experiments, mice were subjected to transient two vessel occlusion (T2VO)-induced cognitive deficits, an animal model of vascular dementia. The T2VO mice were orally treated daily with a standardized extract of B. monnieri $(50 \mathrm{mg} / \mathrm{kg}) 1$ week before and then continuously 3 days after surgery. B. monnieri treatment ameliorated $\mathrm{T} 2 \mathrm{VO}$-induced impairments in non-spatial short-term memory performance in the object recognition test. The mechanism of action was shown to involve protein kinase $\mathrm{C}$ (PKC) and the phosphoinositide-3 kinase/protein kinase $\mathrm{B}$ (PI3K/Akt) pathway. 
Another study evaluated the beneficial effects of daily treatment with an ethanolic extract of B. monnieri $(50 \mathrm{mg} / \mathrm{kg}$, orally, once daily for $2-4$ weeks) on cognitive impairments and neuroregeneration in male Swiss albino mice. The extract contained $22 \%$ bacoside-A and $11 \%$ bacopaside. This mouse model involves neurodegeneration that is induced by trimethyltin, an organotin compound with potent neurotoxic effects that induces neuronal degeneration in humans and rodents. The B. monnieri extract ameliorated cognitive impairments and enhanced neuroregeneration in trimethyltin-treated mice in an object location test and modified Y maze test. The improvement in spatial memory deficits was confirmed by the Nissl staining of hippocampal tissues and propidium iodide staining of organotypic hippocampal slice cultures (Pham et al., 2019).

Kwon et al. (2018), found that a standardized extract of B. monnieri (solvent not specified; 200 $\mathrm{mg} / \mathrm{kg}$, orally, for 4 weeks) improved memory in male C57BL/6J mice by increasing cell proliferation and neuroblast differentiation in the dentate gyrus. The authors suggested that this effect may be related to higher levels of brain-derived neurotrophic factor (BDNF) and cyclic adenosine monophosphate (cAMP) response element binding protein (CREB) phosphorylation in the dentate gyrus.

Thomas et al. (2013), investigated alterations of dopaminergic system function (dopamine $\mathrm{D}_{1}$ and $\mathrm{D}_{2}$ receptor subtypes) in hypoglycemic neonatal rats that were orally treated with an aqueous extract of $B$. monnieri (100 mg/kg for 10 days) and bacoside-A $(50 \mathrm{mg} / \mathrm{kg}$ for 10 days). Neonatal hypoglycemia triggered a series of events that resulted in neuronal death, impairments in spatial learning and memory and cognition, and a decrease in the number of dopamine $\mathrm{D}_{1}$ receptors. Neonatal hypoglycemic rats that were treated with $B$. monnieri and bacoside-A exhibited improvements in $D_{1}$ and $D_{2}$ receptor expression and cAMP signaling and the attenuation of oxidative stress-induced cell death.

Kumar et al. (2016), conducted a randomized, double-blind, placebo-controlled, noncrossover, parallel clinical trial to evaluate the effect of $B$. monnieri on memory in medical students. The 60 participants of both genders received placebo or $150 \mathrm{mg}$ of a standardized methanolic extract of $B$. monnieri twice daily for 6 weeks. B. monnieri significantly improved performance on tests of cognitive function. In 46 health volunteers (age between 18-60 years) that received a standardized ethanolic extract of B. monnieri (300 $\mathrm{mg}$ for 12 weeks) it was observed an improved speed of visual information, learning rate and memory consolidation and state anxiety (Stough et al., 2001).

Roodenrys et al. (2002), also reported the effects of Bacopa monnieri on human memory in a double-blind randomized and placebo control study. Seventy-six adults (age between 40-65 years) received a standardized extract of B. monnieri ( 300 $\mathrm{mg}$ for 12 weeks) presented an increasing in on a test for the retention of new information. The rate of learning, assessing attention, verbal and visual shortterm memory, everyday memory function and anxiety levels were unaffected.

Morgan \& Stevens (2010), investigated the effects of $B$. monnieri on memory performance in healthy elderly subjects in a randomized, doubleblind, placebo-controlled study. The study included 98 healthy participants (> 55 years old, 46 males and 52 females) who were randomized to receive placebo or a standard ethanolic extract of B. monnieri ( 300 $\mathrm{mg} /$ day daily for 12 weeks). Neuropsychological and subjective memory assessments were performed at baseline and after treatment. The extract of $B$. monnieri significantly improved verbal learning, the acquisition of memory, and delayed recall. However, B. monnieri treatment caused adverse gastrointestinal effects, including an increase in stool frequency, abdominal cramps, and nausea.

Peth-Nui et al. (2012), performed a randomized, double-blind, placebo-controlled study to investigate the effects of $B$. monnieri on attention, cognitive processing, working memory, and cholinergic and monoaminergic function. The study included 60 healthy elderly subjects (mean age: 62.6 years, 23 males and 37 females) who received a standardized ethanolic extract of B. monnieri (300 and $600 \mathrm{mg}$ daily for 12 weeks) or placebo. Working memory, attention, and cognitive processing were assessed before treatment, every 4 weeks throughout the study period, and at 4 weeks after the cessation of treatment. B. monnieri improved attention, cognitive processing, and working memory, partially by suppressing acetylcholinesterase (AChE) activity. $B$. monnieri did not cause adverse effects, changes in hematological or biochemical parameters, or electrocardiographic abnormalities.

Calabrese et al. (2008), studied the effects of a standardized methanolic extract of B. monnieri on cognitive performance, anxiety, and depression in a randomized, double-blind, placebo-controlled trial. The study included 48 participants (mean age: 73.5 
years) without clinical signs of dementia who orally received placebo or a $B$. monnieri extract $(300$ $\mathrm{mg}$ /day for 12 weeks). B. monnieri enhanced auditory verbal learning, delayed word recall memory, and performance on the Stroop task. The dose was well tolerated, with no changes in blood pressure and only a few adverse events that primarily involved stomach upset.

The effects of $B$. monnieri on cognitive performance were also investigated in a randomized controlled trial that included 120 male children and adolescents (6-14 years old) with hyperactivity and inattention. The participants were orally treated with placebo or a standardized ethanolic extract of $B$. monnieri (160 and $320 \mathrm{mg} /$ day for 16 weeks) with $\geq 55 \%$ bacosides. B. monnieri improved hyperactivity, inattention, mood, sleep, and cognition (Kean et al., 2015).

\section{Anti-Alzheimer's disease activity}

$B$. monnieri has been suggested to be a promising treatment for Alzheimer's disease, in which a $B$. monnieri extract was shown to counteract neuronal deterioration (Ahn et al., 2016). Several research groups have reviewed the preclinical effects of $B$. monnieri on Alzheimer's disease (Chaudhari et al., 2007; Howes \& Houghton, 2012; Srivastav \& Yadav, 2016). Table No. 2 summarizes the anti-Alzheimer's disease effects of $B$. monnieri.

Table No. 2

Effects of Bacopa monnieri on Alzheimer's disease

\begin{tabular}{|c|c|c|c|c|c|c|}
\hline $\begin{array}{l}\text { Type of } \\
\text { study }\end{array}$ & Extract & Dose & $\begin{array}{l}\text { Time of } \\
\text { treatment }\end{array}$ & Main effects & $\begin{array}{l}\text { Origin of } \\
\text { study }\end{array}$ & Source \\
\hline $\begin{array}{l}\text { Preclinical } \\
\text { (in vitro) }\end{array}$ & Ethanolic & Several & - & $\begin{array}{l}\text { - Inhibition of } \\
\text { amyloid- } \beta \text { and AChE } \\
\text { - Antioxidant effects }\end{array}$ & Thailand & (Limpeanchob et al., 2008) \\
\hline $\begin{array}{l}\text { Preclinical } \\
\text { (in vitro) }\end{array}$ & Ethanolic & Several & - & $\begin{array}{l}\text { - Inhibition of } \\
\text { amyloid- } \beta\end{array}$ & Estonia & (Witter et al., 2018) \\
\hline $\begin{array}{l}\text { Preclinical } \\
\text { (in vitro) }\end{array}$ & Methanolic & Several & - & $\begin{array}{l}\text { - Inhibition of } \\
\text { amyloid- } \beta\end{array}$ & India & $\begin{array}{c}\text { (Mathew \& Subramanian, } \\
\text { 2012) }\end{array}$ \\
\hline $\begin{array}{l}\text { Preclinical } \\
\text { (PSAPP } \\
\text { mice) }\end{array}$ & Ethanolic & $\begin{array}{l}40 \text { and } 60 \\
\mathrm{mg} / \mathrm{kg}\end{array}$ & $\begin{array}{l}4 \text { or } 32 \\
\text { weeks }\end{array}$ & $\begin{array}{c}\text { - Inhibition of } \\
\text { amyloid- } \beta \\
\text { - Improvement in } \\
\text { hyperlocomotion }\end{array}$ & USA & $\begin{array}{c}\text { (Dhanasekaran et al., } \\
\text { 2007) }\end{array}$ \\
\hline $\begin{array}{l}\text { Preclinical } \\
\text { (Wistar rats) }\end{array}$ & Ethanolic & $\begin{array}{l}20,40, \\
\text { and } 80 \\
\mathrm{mg} / \mathrm{kg}\end{array}$ & 3 weeks & $\begin{array}{l}\text { - Improvement in } \\
\text { escape latency } \\
\text { - Decrease in } \\
\text { retention time } \\
\text { - Increasing in } \\
\text { cholinergic neuron } \\
\text { densities }\end{array}$ & Thailand & (Uabundit et al., 2010) \\
\hline $\begin{array}{l}\text { Preclinical } \\
\text { (Wistar rats) }\end{array}$ & $\begin{array}{c}\text { Standardized } \\
\text { (solvent not } \\
\text { specified) }\end{array}$ & $50 \mathrm{mg} / \mathrm{kg}$ & 2 weeks & $\begin{array}{l}\text { - Reversal of } \\
\text { memory impairment } \\
\text { - Inhibition of AChE } \\
\text { - Antioxidant effects }\end{array}$ & India & (Saini et al., 2012) \\
\hline $\begin{array}{l}\text { Preclinical } \\
\text { (Wistar rats) }\end{array}$ & $\begin{array}{l}\text { Standardized } \\
\text { (solvent not } \\
\text { specified) }\end{array}$ & $50 \mathrm{mg} / \mathrm{kg}$ & 2 weeks & $\begin{array}{l}\text { - Anti-inflammatory } \\
\text { effects }\end{array}$ & India & (Saini et al., 2019) \\
\hline
\end{tabular}




\begin{tabular}{|c|c|c|c|c|c|c|}
\hline $\begin{array}{l}\text { Preclinical } \\
\text { (in vitro and } \\
\text { in Swiss } \\
\text { mice) }\end{array}$ & Ethanolic & $30 \mathrm{mg} / \mathrm{kg}$ & 1 week & $\begin{array}{c}\text { - Inhibition of } \mathrm{AChE} \\
\text { - Antidementia } \\
\text { effects }\end{array}$ & India & (Das et al., 2002) \\
\hline $\begin{array}{c}\text { Preclinical } \\
\text { (Swiss mice) }\end{array}$ & $\begin{array}{l}\text { Standardized } \\
\text { (solvent not } \\
\text { specified) }\end{array}$ & $\begin{array}{c}120 \\
\mathrm{mg} / \mathrm{kg}\end{array}$ & $\begin{array}{l}\text { Single } \\
\text { dose }\end{array}$ & $\begin{array}{l}\text { - Improvements in } \\
\text { calmodulin and } \\
\text { memory }\end{array}$ & India & (Saraf et al., 2009) \\
\hline $\begin{array}{c}\text { Preclinical } \\
\text { (Wistar rats) }\end{array}$ & Bacosides & $\begin{array}{c}200 \\
\mathrm{mg} / \mathrm{kg}\end{array}$ & 12 weeks & $\begin{array}{l}\text { - Improvements in } \\
\text { neurotransmitter } \\
\text { systems, behavioral } \\
\text { paradigms, and } \\
\text { hippocampal } \\
\text { neuronal loss } \\
\text { - Antioxidant effects }\end{array}$ & India & (Rastogi et al., 2012b) \\
\hline $\begin{array}{c}\text { Preclinical } \\
\text { (Wistar rats) }\end{array}$ & Bacoside & $\begin{array}{c}50,100, \\
200,400, \\
\text { and } 800 \\
\mathrm{mg} / \mathrm{kg}\end{array}$ & 12 weeks & $\begin{array}{l}\text { - Neuroprotective } \\
\text { effects through } \\
\text { pleiotropic actions } \\
\text { for the prevention of } \\
\text { aging-related } \\
\text { complications and } \\
\text { senile dementia of } \\
\text { Alzheimer's } \\
\text { progression }\end{array}$ & India & (Rastogi et al., 2012a) \\
\hline
\end{tabular}

Limpeanchob et al. (2008), evaluated the in vitro neuroprotective effects of an extract of $B$. monnieri against amyloid- $\beta_{25-35}$ protein and glutamate-induced neurotoxicity in primary cortical cultured neurons. The ethanolic extract at different concentrations protected neurons from cell death but not glutamate-induced excitotoxicity. This effect was mediated by the suppression of AChE activity, a decrease in intracellular oxidative stress, and a decrease in lipid peroxidation. The inhibitory effects of ethanolic and methanolic extracts of $B$. monnieri on amyloid- $\beta$ oligomerization and fibrillation were also investigated by Witter et al. (2018) and Mathew and Subramanian (2012), respectively.

The anti-amyloidogenic potential of $B$. monnieri was evaluated in a transgenic amyloid- $\beta$ peptide-overproducing PSAPP mouse model of Alzheimer's disease. Male and female PSAPP mice were treated with an ethanolic extract of $B$. monnieri (40 and $60 \mathrm{mg} / \mathrm{kg}$, orally, for 4 or 32 weeks). Treatment with the extract decreased amyloid- $\beta_{1-40}$ and amyloid- $\beta_{1-42}$ levels in the cortex by as much as $60 \%$ and reversed hyperlocomotion in PSAPP mice (Holcomb et al., 2006). The effects of B. monnieri in reduce beta-amyloid levels in ex vivo brain of PSAPP mice were also evaluated by Dhanasekaran et al. (2007). The ethanolic extract of B. monnieri (50 $1000 \mu \mathrm{g}$ ) reduced components of the oxidative stress cascade and decreased lipoxygenase activity.

Uabundit et al. (2010), investigated the effect of an ethanolic extract of $B$. monnieri on cognitive function and neurodegeneration in an animal model of Alzheimer's disease that was induced by ethylcholine aziridinium. Male Wistar rats were orally treated with the extract $(20,40$, and $80 \mathrm{mg} / \mathrm{kg})$ for 2 weeks before and 1 week after induction of the model. Treatment with all doses of the extract improved the escape latency and decreased retention time in the Morris water maze. The low dose of the B. monnieri extract increased cholinergic neuron densities in all areas of the hippocampus. No correlation was found between the cognitionenhancing effect and neuroprotective effect of the extract, suggesting different mechanisms of action of B. monnieri.

The effects of $B$. monnieri on colchicineinduced dementia (i.e., a model of Alzheimer's disease) were also evaluated. Male Wistar rats 
received colchicine (3 $\mu \mathrm{g} / \mu \mathrm{L}$, intracerebroventricularly) and then were orally treated with a standardized extract of $B$. monnieri (solvent not specified; $50 \mathrm{mg} / \mathrm{kg} / \mathrm{day}$ for 2 weeks). Cognitive performance was evaluated in the elevated plus maze, and motor function was evaluated in the rotarod test. Colchicine induced neurobehavioral deficits, increased $\mathrm{AChE}$ activity, inhibited $\mathrm{Na}^{+} / \mathrm{K}^{+}$ ATPase activity, and induced brain oxidative stress, reflected by higher levels of lipid peroxidation and protein carbonyls and a decrease in the activity of antioxidant enzymes. Supplementation with the $B$. monnieri extract reversed memory impairments, restored the activity of antioxidant enzymes, and attenuated oxidative damage (Saini et al., 2012).

Using the same model of colchicine-induced dementia, Saini et al. (2019), evaluated the antiinflammatory effects of a standardized extract of $B$. monnieri (solvent not specified; $50 \mathrm{mg} / \mathrm{kg}$ for 2 weeks) in male Wistar rats. Colchicine increased $\beta$ amyloid production, induced oxidative stress, increased the expression of proinflammatory cytokines (interleukin-6 [IL-6] and tumor necrosis factor $\alpha[\mathrm{TNF}-\alpha]$ ) and chemokines (monocyte chemoattractant protein-1 [MCP-1]), and increased the expression of cyclooxygenase-2 (COX-2) and inducible nitric oxide synthase (iNOS) in the brain. Treatment with the B. monnieri extract reversed all of these alterations.

Das et al. (2002), evaluated the antidementia activity of $B$. monnieri against deficits that were induced by the anticholinergic drug scopolamine (3 $\mathrm{mg} / \mathrm{kg}$, intraperitoneally) in the passive avoidance test. In male Swiss mice, oral administration of an ethanolic extract of $B$. monnieri $(30 \mathrm{mg} / \mathrm{kg}$ for 1 week) significantly increased the transfer latency and no transfer response in the second trial after scopolamine treatment, thus attenuating its antidementia effect. The extract dose-dependently inhibited AChE activity in vitro.

Saraf et al. (2009), investigated the protective mechanism of action of $B$. monnieri against scopolamine-induced amnesia in male Swiss mice. In the brain, scopolamine downregulated PKC and iNOS without affecting cAMP, PKA, calmodulin, mitogen-activated protein kinase (MAPK), nitrite, CREB, or phosphorylated CREB. Treatment with a standardized extract of $B$. trimera (solvent not specified; $120 \mathrm{mg} / \mathrm{kg}$, single dose, orally or intraperitoneally) reversed scopolamine-induced amnesia by significantly increasing calmodulin levels and partially decreasing PKC and pCREB levels.
In addition to crude and standardized extracts of B. monnieri, bacopasides have also been evaluated in an animal model of Alzheimer's disease. Bacoside $(200 \mathrm{mg} / \mathrm{kg}$ ) was orally administered for 12 weeks in male Wistar rats (17-18 months old or $>2$ years old). The treatment protected animals against agingassociated alterations of neurotransmission systems, behavior, hippocampal neuronal loss, and oxidative stress (Rastogi et al., 2012b).

Rastogi et al. (2012b), used the isolated compound bacoside that was dissolved in sodium sulphate buffer $(0.05 \mathrm{M}, \mathrm{pH} 2.3)$ and acetonitrile (50:50, volume/volume). Long-term oral bacoside administration significantly decreased age-dependent elevations of proinflammatory cytokines, iNOS protein expression, total nitrite, and lipofuscin content in the cortex in middle-aged and aged female Wistar rats. These results suggest that bacoside may have potential as a neuroprotective agent based on its pleiotropic actions in preventing aging-associated complications and Alzheimer's-type senile dementia.

Despite the promising preclinical effects of B. monnieri against Alzheimer's disease, no clinical studies have yet investigated the plant's effects on the disease. One study investigated the effects of treatment with $B$. monnieri combined with other medicinal species (Hippophae rhamnoides and Dioscorea bulbifera), reporting positive effects on cognitive function in human patients with Alzheimer's-associated senile dementia (Sadhu et al., 2014).

\section{Antiparkinson activity}

The antiparkinsonian activity of B. monnieri has been investigated in vitro and in several models of neurodegenerative disease. The antioxidant and neuroprotective effects of $B$. monnieri confer antiParkinsonian activity of the plant that is associated with lower $\alpha$-synuclein protein aggregation and the selective death of dopaminergic neurons. Table No. 3 summarizes the antiparkinsonian effects of $B$. monnieri.

In N27 cell lines (dopaminergic cells) that were pretreated with an ethanolic extract of $B$. monnieri, a cytoprotective effect was observed, reflected by the attenuation of rotenone-induced oxidative stress and cell death (Shinomol et al., 2012).

Jadiya et al. (2011), evaluated the antiParkinsonian effects of a concentrated mother tincture of a $B$. monnieri extract in two different Caenorhabditis elegans nematode models. The 
transgenic model expressed human $\alpha \mathrm{a}$-synuclein, and the pharmacological model expressed green fluorescent protein specifically in dopaminergic neurons that were treated with the selective catecholaminergic neurotoxin 6-hydroxydopamine
(6-OHDA). B. monnieri reduced $\alpha$-synuclein aggregation, prevented dopaminergic neurodegeneration, and restored lipid content in nematodes, demonstrating the possible antiParkinsonian potential of this species.

Table No. 3

Effects of Bacopa monnieri on Parkinson's disease

\begin{tabular}{|c|c|c|c|c|c|c|}
\hline $\begin{array}{l}\text { Type of } \\
\text { study }\end{array}$ & Extract & Dose & $\begin{array}{c}\text { Time of } \\
\text { treatment }\end{array}$ & Main effects & $\begin{array}{l}\text { Origin of } \\
\text { study }\end{array}$ & Source \\
\hline $\begin{array}{l}\text { Preclinical } \\
\text { (in vitro) }\end{array}$ & Ethanolic & $2-6 \mu \mathrm{g} / \mathrm{L}$ & $24 \mathrm{~h}$ & $\begin{array}{l}\text { • Cytoprotective effect, } \\
\text { revealed by the attenuation of } \\
\text { rotenone-induced oxidative } \\
\text { stress and cell death }\end{array}$ & India & $\begin{array}{l}\text { (Shinomol et } \\
\text { al., 2012) }\end{array}$ \\
\hline $\begin{array}{l}\text { Preclinical } \\
\text { (C. elegans) }\end{array}$ & $\begin{array}{l}\text { Mother } \\
\text { tincture }\end{array}$ & $\begin{array}{l}\text { The mother } \\
\text { tincture was } \\
\text { diluted tenfold } \\
\text { in OP50 }\end{array}$ & - & $\begin{array}{c}\text { - Reduction of } \alpha \text {-synuclein } \\
\text { aggregation } \\
\text { - Prevention of dopaminergic } \\
\text { neurodegeneration } \\
\text { - Restoration of lipid content } \\
\text { in nematodes }\end{array}$ & India & $\begin{array}{l}\text { (Jadiya et al., } \\
\text { 2011) }\end{array}$ \\
\hline $\begin{array}{l}\text { Preclinical } \\
\text { (Drosophila) }\end{array}$ & $\begin{array}{l}\text { Standardized } \\
\text { (solvent not } \\
\text { specified) }\end{array}$ & $\begin{array}{c}0.05 \% \text { and } \\
0.1 \%\end{array}$ & 1 week & $\begin{array}{l}\text { - Reduction of endogenous } \\
\text { markers oxidative stress } \\
\text { - Inhibition of dopamine } \\
\text { depletion } \\
\text { - Lower incidence of } \\
\text { mortality }\end{array}$ & India & $\begin{array}{l}\text { (Hosamani } \\
\quad \& \\
\text { Muralidhara, } \\
\text { 2009) }\end{array}$ \\
\hline $\begin{array}{l}\text { Preclinical } \\
\text { (Drosophila) }\end{array}$ & $\begin{array}{l}\text { Standardized } \\
\text { (solvent not } \\
\text { specified) }\end{array}$ & $\begin{array}{c}0.05 \% \text { and } \\
0.1 \%\end{array}$ & $24 \mathrm{~h}$ & $\begin{array}{l}\text { - Restoration of electron } \\
\text { transport chain and } \\
\text { antioxidant and } \\
\text { neuroprotective activity }\end{array}$ & India & $\begin{array}{l}\text { (Hosamani } \\
\& \\
\text { Muralidhara, } \\
\text { 2010) }\end{array}$ \\
\hline $\begin{array}{l}\text { Preclinical } \\
\text { (Drosophila) }\end{array}$ & $\begin{array}{l}\text { Standardized } \\
\text { (solvent not } \\
\text { specified) }\end{array}$ & $\begin{array}{c}11 \mathrm{mg} / 100 \mathrm{~g} \\
\text { of food }\end{array}$ & 2 weeks & $\begin{array}{l}\text { - Improvement in climbing } \\
\text { ability } \\
\text { - Normalization of markers } \\
\text { of oxidative stress }\end{array}$ & UK & $\begin{array}{c}\text { (Jansen et al., } \\
\text { 2014) }\end{array}$ \\
\hline $\begin{array}{l}\text { Preclinical } \\
\text { (Drosophila) }\end{array}$ & Acetone & $\begin{array}{c}0.25,0.50, \text { and } \\
1.0 \mu \mathrm{l} / \mathrm{ml}\end{array}$ & 24 days & $\begin{array}{l}\text { - Improvement of behavioral } \\
\text { abnormalities } \\
\text { - Normalization of markers } \\
\text { of oxidative stress }\end{array}$ & India & $\begin{array}{l}\text { (Siddique et } \\
\text { al., 2014) }\end{array}$ \\
\hline $\begin{array}{l}\text { Preclinical } \\
\text { (Drosophila) }\end{array}$ & $\begin{array}{l}\text { Standardized } \\
\text { (solvent not } \\
\text { specified) }\end{array}$ & $\begin{array}{c}0.1 \% \text { in the } \\
\text { diet }\end{array}$ & $48 \mathrm{~h}$ & $\begin{array}{l}\text { - Reduction of paraquat- } \\
\text { induced toxicity } \\
\text { - Optimization of active JNK } \\
\text { protein and cleaved caspase-3 } \\
\text { activity } \\
\text { - Stabilization of oxidative }\end{array}$ & India & $\begin{array}{l}\text { (Srivastav et } \\
\text { al., 2018) }\end{array}$ \\
\hline
\end{tabular}

Boletín Latinoamericano y del Caribe de Plantas Medicinales y Aromáticas / 143 


\begin{tabular}{|c|c|c|c|c|c|c|}
\hline & & & & and apoptotic processes & & \\
\hline $\begin{array}{l}\text { Preclinical } \\
\text { (zebrafish) }\end{array}$ & $\begin{array}{l}\text { Standardized } \\
\text { aqueous } \\
\text { extract } \\
\text { encapsulated } \\
\text { in } \\
\text { nanoparticles }\end{array}$ & $\begin{array}{l}0.3,0.4 \text {, and } \\
0.5 \mu \mathrm{mol} / \mathrm{kg}\end{array}$ & 5 days & $\begin{array}{l}\text { - Neuroprotection against } \\
\text { MPTP-induced toxicity }\end{array}$ & India & $\begin{array}{l}\text { (Nellore et } \\
\text { al., 2013) }\end{array}$ \\
\hline $\begin{array}{l}\text { Preclinical } \\
\text { (Swiss } \\
\text { mice) }\end{array}$ & Ethanolic & $10 \mathrm{mg} / \mathrm{kg}$ & 1 week & $\begin{array}{l}\text { - Normalization of markers } \\
\text { of oxidative stress } \\
\text { - Restoration of antioxidant } \\
\text { enzyme activity, } \\
\text { neurotransmitter activity, and } \\
\text { dopamine levels }\end{array}$ & India & $\begin{array}{l}\text { (Shinomol et } \\
\text { al., 2012) }\end{array}$ \\
\hline $\begin{array}{l}\text { Preclinical } \\
\text { (Swiss } \\
\text { mice) }\end{array}$ & $\begin{array}{c}\text { Standardized } \\
\text { (solvent not } \\
\text { specified) }\end{array}$ & $200 \mathrm{mg} / \mathrm{kg}$ & 4 weeks & $\begin{array}{c}\text { - Prevention of oxidation- } \\
\text { mediated neuronal } \\
\text { dysfunction }\end{array}$ & USA & $\begin{array}{l}\text { (Hosamani et } \\
\text { al., 2016) }\end{array}$ \\
\hline $\begin{array}{l}\text { Preclinical } \\
\text { (Swiss } \\
\text { mice) }\end{array}$ & Ethanolic & $40 \mathrm{mg} / \mathrm{kg}$ & 30 days & $\begin{array}{l}\text { - Increase in locomotor } \\
\text { activity } \\
\text { - Increase in tyrosine } \\
\text { hydroxylase and caspase-3 } \\
\text { activity and gene expression } \\
\text { in the substantia nigra }\end{array}$ & India & $\begin{array}{l}\text { (Singh et al., } \\
\text { 2016) }\end{array}$ \\
\hline $\begin{array}{l}\text { Preclinical } \\
\text { (Swiss } \\
\text { mice) }\end{array}$ & Ethanolic & $40 \mathrm{mg} / \mathrm{kg}$ & 30 days & $\begin{array}{l}\text { - Improvement in motor } \\
\text { behavior through a decrease } \\
\text { in oxidative stress and } \\
\text { apoptosis and increase in } \\
\text { dopamine level and Bcl-2 } \\
\text { protein expression }\end{array}$ & India & $\begin{array}{l}\text { Singh et al., } \\
\text { 2017) }\end{array}$ \\
\hline $\begin{array}{l}\text { Preclinical } \\
\text { (Swiss } \\
\text { mice) }\end{array}$ & $\begin{array}{c}\text { Standardized } \\
\text { (solvent not } \\
\text { specified) }\end{array}$ & $200 \mathrm{mg} / \mathrm{kg}$ & 3 weeks & $\begin{array}{c}\text { - Decrease in paraquat- } \\
\text { induced cognitive deficits and } \\
\text { oxidative stress } \\
\text { - Restoration of dopamine } \\
\text { levels and decreased } \\
\text { cholinergic activity in the } \\
\text { striatum }\end{array}$ & India & $\begin{array}{l}\text { (Krishna et } \\
\text { al., 2019) }\end{array}$ \\
\hline
\end{tabular}

The neuroprotective effects of a standardized extract of $B$. monnieri (solvent not specified; provided in the diet for 1 week) against rotenoneinduced oxidative damage and neurotoxicity were also evaluated in a Drosophila melanogaster model of Parkinson's disease. In flies that were exposed to the extract, significantly lower levels of endogenous oxidative markers were observed, with the inhibition of dopamine depletion and a lower incidence of mortality, suggesting the neuroprotective potential of
B. monnieri (Hosamani \& Muralidhara, 2009).

A study of adult male Drosophila melanogaster evaluated the prophylactic efficacy of a standardized extract of $B$. monnieri (solvent not specified; provided in the diet for $24 \mathrm{~h}$ ) that contained approximately $40 \%$ bacoside against paraquatinduced oxidative stress, mitochondrial dysfunction, and lethality. The B. monnieri extract prevented paraquat-induced oxidative stress and neurotoxicity and restored the activity of electron transport chain 
complexes, suggesting a specific effect on mitochondria and neuroprotective efficacy (Hosamani \& Muralidhara, 2010).

The therapeutic potential of a standardized extract of $B$. monnieri (solvent not specified; provided in the diet for 2 weeks) to relieve motor symptoms of Parkinson's disease was studied in a simple model with two types of flies. Improvements in climbing ability were observed only in the PINK1 D. melanogaster transgenic model, which may be explained by the presence of antioxidants in $B$. monnieri that decreased the sensitivity to oxidative stress. PINK1 flies are usually more sensitive to oxidative stress. Moreover, in PINK1 flies, higher plasma levodopa levels improved locomotion, whereas healthy wildtype flies did not exhibit such positive results, which can be attributed to a higher likelihood of side effects from treatment resulting in dyskinesia resulting in decreased ability to climb wild-type flies (Jansen et al., 2014).

Siddique et al. (2014), evaluated the effects of an acetone extract of B. monnieri $(0.25,0.50$, and $1.0 \mu \mathrm{L} / \mathrm{mL}$ for 24 days) in a Drosophila sp. transgenic line that expressed human $\alpha$-synuclein. $B$. monnieri improved behavioral abnormalities and reduced oxidative stress and apoptosis in this fly model of Parkinson's disease.

Srivastav et al. (2018), investigated the effects of a standardized extract of $B$. monnieri (solvent not specified; $1 \%$ concentration provided in the diet for $48 \mathrm{~h}$ ) against paraquat-induced toxicity in a D. melanogaster model of Parkinson's disease. $B$. monnieri decreased acute paraquat-induced toxicity by optimizing redox balance and mitochondrial function, decreasing apoptosis, optimizing active cJun N-terminal kinase (JNK) protein and cleaved caspase- 3 activity, and stabilizing the transcriptional regulation of genes that are responsible for regulating apoptosis and oxidative stress. These findings further demonstrated the potential of $B$. monnieri as a neuroprotective agent.

Nellore et al. (2013), evaluated the neuroprotective effects of a platinum nanoparticleencapsulated aqueous extract of $B$. monnieri (alternating days of treatment for 5 days) in a zebrafish model of 1-methyl-4-phenyl-1,2,3,6tetrahydropyridine (MPTP)-induced Parkinson's disease. B. monnieri pretreatment significantly reversed the toxic effects of MPTP, increased the levels of dopamine and its metabolites, increased glutathione levels, increased glutathione peroxidase, catalase, superoxide dismutase, and mitochondrial complex I activity, decreased malondialdehyde levels, and increased locomotor activity. These findings suggest that the protective potential of $B$. monnieri against MPTP-induced neurotoxicity occurs through dual actions on mitochondrial complex I and antioxidant activity.

Treatment with an ethanolic extract of $B$. monnieri $(10 \mathrm{mg} / \mathrm{kg}$, intraperitoneally, for 7 days) exerted neuroprotective effects in male Swiss mice that received rotenone. Treatment with the extract restored the activity of cytosolic antioxidant enzymes, restored reduced glutathione levels, and normalized oxidative markers, protein carbonyl content, neurotransmitter function, and cellular dopamine levels, thus further demonstrating the potent neuroprotective effects of the plant (Shinomol et al., 2012).

Treatment with a standardized extract of $B$. monnieri (solvent not specified; $200 \mathrm{mg} / \mathrm{kg}$ for 4 weeks) in prepubertal male Swiss mice exerted significant antioxidant effects. Treatment with the extract improved oxidative homeostasis, decreased paraquat-induced reactive oxygen species, reduced mitochondrial dysfunction, and decreased malondialdehyde and hydroperoxide levels in various brain regions (Hosamani et al., 2016).

Singh et al. (2017), evaluated the neuroprotective effects of an ethanolic extract of $B$. monnieri $(40 \mathrm{mg} / \mathrm{kg}$, orally, for 30 days) in a model of MPTP-induced Parkinson's disease in male Swiss mice. Treatment with B. monnieri improved motor behavior, reduced oxidative stress and apoptosis, increased dopamine levels, and increased B-cell lymphoma 2 (Bcl-2) protein expression, indicating a dopaminergic neuroprotective effect against Parkinson's disease that occurred through the modulation of oxidative stress and apoptotic factors.

Singh et al. (2016), also evaluated the therapeutic effects of an ethanolic extract of $B$. monnieri in a model of MPTP-induced Parkinson's disease in male Swiss mice that were orally treated with an extract of B. monnieri (40 mg/kg, orally, for 30 days). B. monnieri significantly decreased oxidative stress, increased locomotor activity, and increased tyrosine hydroxylase and caspase-3 activity and gene expression in the substantia nigra. These results indicate that $B$. monnieri promotes neurogenesis, reduces apoptosis, and restores the concentration of dopamine and its metabolites.

Male Swiss mice were orally supplemented with a standardized extract of $B$. monnieri (solvent not specified; $200 \mathrm{mg} / \mathrm{kg}$ for 3 weeks), and anxiety- 
like behavior, motor function, and biochemical changes in specific brain areas were examined. Supplementation with B. monnieri decreased paraquat-induced cognitive deficits and oxidative stress, increased dopamine levels, and reversed cholinergic activity in the striatum (Krishna et al., 2019).

\section{Antiepileptic activity}

Many drugs that are used to treat epilepsy may cause cognitive deficits (Kwan \& Brodie, 2001). A renewed interest has been seen in the use of traditional medicinal plant formulations to treat epilepsy and exert neuroprotective effects. However, despite the widespread therapeutic use of medicinal plants, little is known about their effectiveness and toxicity (Liu et al., 2017b). B. monnieri exerts interesting preclinical antiepileptic effects on many pathways that are involved in epilepsy, but robust preclinical research and clinical studies are still lacking to fully evaluate the therapeutic potential of this species. The antiepileptic effects of $B$. monnieri are summarized in Table No. 4.

Table No. 4

Effects of Bacopa monnieri on epilepsy

\begin{tabular}{|c|c|c|c|c|c|c|}
\hline Type of study & Extract & Dose & $\begin{array}{l}\text { Time of } \\
\text { treatment }\end{array}$ & Main effects & $\begin{array}{l}\text { Origin of } \\
\text { study }\end{array}$ & Source \\
\hline $\begin{array}{l}\text { Preclinical } \\
\text { (Wistar rats) }\end{array}$ & Aqueous & $\begin{array}{c}300 \\
\mathrm{mg} / \mathrm{kg}\end{array}$ & 2 weeks & $\begin{array}{l}\text { - Regulation of NMDA } \\
\text { receptor } 1 \\
\text { - Increase in glutamate } \\
\text { dehydrogenase activity } \\
\text { - Increase in escape } \\
\text { latency }\end{array}$ & India & $\begin{array}{l}\text { (Khan et al., } \\
\text { 2008) }\end{array}$ \\
\hline $\begin{array}{l}\text { Preclinical } \\
\text { (Wistar rats) }\end{array}$ & Aqueous & $\begin{array}{c}150 \\
\mathrm{mg} / \mathrm{kg}\end{array}$ & 2 weeks & $\begin{array}{c}\text { - Regulation of mGluR8 } \\
\text { expression }\end{array}$ & India & $\begin{array}{l}\text { (Paulose } \text { et al., } \\
\text { 2008) }\end{array}$ \\
\hline $\begin{array}{l}\text { Preclinical } \\
\text { (Wistar rats) }\end{array}$ & $\begin{array}{l}\text { Aqueous and } \\
\text { bacoside-A }\end{array}$ & $\begin{array}{c}150 \text { and } \\
300 \\
\mathrm{mg} / \mathrm{kg}\end{array}$ & 2 weeks & $\begin{array}{l}\text { - Normalization of GABA } \\
\text { levels, GABA } A_{A} \text { and } \\
\text { GABA }_{B} \text { receptor binding, } \\
\text { and CREB gene } \\
\text { expression in the striatum }\end{array}$ & India & $\begin{array}{l}\text { (Mathew et al., } \\
\text { 2010a) }\end{array}$ \\
\hline $\begin{array}{l}\text { Preclinical } \\
\text { (Wistar rats) }\end{array}$ & $\begin{array}{l}\text { Aqueous and } \\
\text { bacoside-A }\end{array}$ & $\begin{array}{c}150 \text { and } \\
300 \\
\mathrm{mg} / \mathrm{kg}\end{array}$ & 2 weeks & $\begin{array}{l}\text { - Normalization of GABA } \\
\text { levels, GABA } A_{A} \text { and } \\
\text { GABA } A_{B} \text { receptor binding, } \\
\text { and CREB gene } \\
\text { expression in the } \\
\text { hippocampus }\end{array}$ & India & $\begin{array}{l}\text { (Mathew et al., } \\
\text { 2011) }\end{array}$ \\
\hline $\begin{array}{l}\text { Preclinical } \\
\text { (Wistar rats) }\end{array}$ & $\begin{array}{l}\text { Aqueous and } \\
\text { bacoside-A }\end{array}$ & $\begin{array}{c}150 \text { and } \\
300 \\
\mathrm{mg} / \mathrm{kg}\end{array}$ & 2 weeks & $\begin{array}{c}\text { - Antiepileptic effects by } \\
\text { attenuating impairments } \\
\text { in the peripheral nervous } \\
\text { system }\end{array}$ & India & $\begin{array}{l}\text { (Mathew et al., } \\
\text { 2010b) }\end{array}$ \\
\hline $\begin{array}{l}\text { Preclinical } \\
(\text { C. elegans })\end{array}$ & Bacoside-A & $\begin{array}{c}0.25 \% \\
0.1 \% \\
\text { and } \\
0.01 \%\end{array}$ & - & Antiepileptic & India & $\begin{array}{l}\text { (Pandey et al., } \\
\text { 2010) }\end{array}$ \\
\hline Preclinical & Aqueous & 150 & 2 weeks & - Normalization of & India & (Krishnakumar et \\
\hline
\end{tabular}




\begin{tabular}{|c|c|c|c|c|c|c|}
\hline (Wistar rats) & & $\mathrm{mg} / \mathrm{kg}$ & & $\begin{array}{c}\text { cerebellar } 5 \text {-HT content, } \\
5-\mathrm{HT}_{2 \mathrm{C}} \text { gene expression, } \\
\text { and } 5-\mathrm{HT}_{2 \mathrm{C}} \text { receptor } \\
\text { binding }\end{array}$ & & al., 2009a) \\
\hline $\begin{array}{l}\text { Preclinical } \\
\text { (Wistar rats) }\end{array}$ & Aqueous & $\begin{array}{c}150 \\
\mathrm{mg} / \mathrm{kg}\end{array}$ & 2 weeks & $\begin{array}{l}\text { • Normalization of } \\
\text { hippocampal 5-HT } \\
\text { content, 5-HT } 2 \mathrm{C} \text { gene } \\
\text { expression, and 5-HT } 2 \mathrm{C} \\
\text { receptor binding }\end{array}$ & India & $\begin{array}{c}\text { (Krishnakumar et } \\
\text { al., 2009b) }\end{array}$ \\
\hline
\end{tabular}

Khan et al. (2008), evaluated the neuroprotective effects of an aqueous extract of $B$. monnieri in male Wistar rats. Epilepsy was induced by an intraperitoneal injection of pilocarpine, and seizures were assessed by observing behavioral postures. Treatment with $B$. monnieri $(300 \mathrm{mg} / \mathrm{kg}$ for 2 weeks) reversed the expression of $N$-methyl-Daspartate (NMDA) receptor 1 and glutamate receptor binding alterations in the hippocampus, increased the activity of glutamate dehydrogenase, and reversed the increase in escape latency in the Morris water maze.

Paulose et al. (2008), investigated the involvement of metabotropic glutamate receptor 8 (mGluR8). During epilepsy, mGluR8 gene expression was downregulated, and the time spent in the platform quadrant decreased in the Morris water maze. Oral treatment with an aqueous extract of $B$. monnieri $(150 \mathrm{mg} / \mathrm{kg}$ for 2 weeks) reversed mGluR8 gene expression and the time spent in the platform quadrant to control levels.

Using the same animal model of pilocarpineinduced epilepsy, Mathew et al. (2010b) and Mathew et al. (2011) evaluated the effects of an aqueous extract of B. monnieri (300 $\mathrm{mg} / \mathrm{kg}$ for 2 weeks) and bacoside-A (150 mg/kg for 2 weeks) in male Wistar rats. Oral treatment with $B$. monnieri and bacoside-A reversed the alterations of GABA levels, $\mathrm{GABA}_{\mathrm{A}}$ and $\mathrm{GABA}_{B}$ receptor binding, and CREB gene expression in the striatum and hippocampus, resulting in an increase in the GABA-mediated inhibition of overstimulated neurons in the cerebral cortex in rats. Mathew et al. (2010a) used the same model, animals, and treatment conditions and found that repetitive seizures resulted in an increase in metabolism and excitability, and treatment with the $B$. monnieri extract and bacoside-A exerted antiepileptic effects by attenuating impairments in the peripheral nervous system. Bacoside-A was also evaluated by Pandey et al. (2010) in a C. elegans model of epilepsy, who found that $0.25 \%, 0.1 \%$, and $0.01 \%$ bacoside-A reduced seizures/convulsions.

In addition to the actions of $B$. monnieri on GABA receptors, the involvement of 5-HT receptors has also been investigated. In a male Wistar rat model of pilocarpine-induced epilepsy, Krishnakumar et al. (2009a) found that treatment with an aqueous extract of B. monnieri $(150 \mathrm{mg} / \mathrm{kg}$ for 2 weeks) normalized cerebellar 5-HT content, 5- $\mathrm{HT}_{2 \mathrm{C}}$ gene expression, 5$\mathrm{HT}_{2 \mathrm{C}}$ receptor binding, and motor dysfunction that were induced by pilocarpine. The same effects were observed in the hippocampus in rats that were orally treated with an aqueous extract of B. monnieri (150 $\mathrm{mg} / \mathrm{kg}$ for 2 weeks) (Krishnakumar et al., 2009b).

\section{Anti-schizophrenia activity}

Since the most common drugs for treating schizophrenia can cause serious side effects, more effective and safe drugs are needed, especially to address cognitive impairments (Piyabhan et al., 2016). In this line, B. monnieri is a promising medicinal plant for the treatment of schizophrenia (Table No. 5).

Piyabhan et al. (2016), and Piyabhan \& Wetchateng (2015), evaluated the cognitive and neuroprotective effects of $B$. monnieri in a model of phencyclidine-induced schizophrenia in male Wistar rats. The animals orally received a standardized extract of B. monnieri ( $40 \mathrm{mg} / \mathrm{kg}$ for 2 weeks) before (neuroprotective study) and after (therapeutic study) phencyclidine administration. B. monnieri prevented cognitive impairment by elevating vesicular glutamate transporter 3 (VGLUT3) immunodensity in the prefrontal cortex and striatum and VGLUT2 immunodensity in the prefrontal cortex. Therapeutic treatment with the extract also effectively reversed cognitive deficits by decreasing NMDA receptor 1 in the CA2 and CA3 areas of the hippocampus (Piyabhan \& Wetchateng, 2014). 
Sarkar et al. (2012), reported a case study of the effects of B. monnieri in schizophrenia. A 34year-old man with a diagnosis of paranoid schizophrenia received two tablets of $B$. monnieri daily for 4 weeks. Each tablet contained $250 \mathrm{mg}$ of $B$. monnieri extract. B. monnieri reduced psychopathology without any treatment-emergent adverse effects.

Table No. 5

Effects of Bacopa monnieri on schizophrenia

\begin{tabular}{|c|c|c|c|c|c|c|}
\hline $\begin{array}{c}\text { Type of } \\
\text { study }\end{array}$ & Extract & Dose & $\begin{array}{c}\text { Time of } \\
\text { treatment }\end{array}$ & Main effects & $\begin{array}{c}\text { Origin of } \\
\text { study }\end{array}$ & Source \\
\hline $\begin{array}{l}\text { Preclinical } \\
\text { (Wistar } \\
\text { rats) }\end{array}$ & Standardized & $\begin{array}{c}40 \mathrm{mg} / \mathrm{kg} \text { before } \\
\text { and after model } \\
\text { induction }\end{array}$ & 2 weeks & $\begin{array}{l}\text { - Prevention of cognitive } \\
\text { impairment by elevating } \\
\text { VGLUT3 immunodensity } \\
\text { in the prefrontal cortex } \\
\text { and striatum }\end{array}$ & Thailand & $\begin{array}{l}\text { (Piyabhan et } \\
\text { al., 2016) }\end{array}$ \\
\hline $\begin{array}{l}\text { Preclinical } \\
\text { (Wistar } \\
\text { rats) }\end{array}$ & Standardized & $\begin{array}{l}40 \mathrm{mg} / \mathrm{kg} \text { before } \\
\text { and after model } \\
\text { induction }\end{array}$ & 2 weeks & $\begin{array}{l}\text { - Prevention of cognitive } \\
\text { impairment by elevating } \\
\text { VGLUT2 immunodensity } \\
\text { in the prefrontal cortex }\end{array}$ & Thailand & $\begin{array}{l}\text { (Piyabhan and } \\
\text { Wetchateng, } \\
\text { 2015) }\end{array}$ \\
\hline $\begin{array}{l}\text { Preclinical } \\
\text { (Wistar } \\
\text { rats) }\end{array}$ & Standardized & $\begin{array}{c}40 \mathrm{mg} / \mathrm{kg} \text { before } \\
\text { and after model } \\
\text { induction }\end{array}$ & 2 weeks & $\begin{array}{l}\text { - Restoration of cognitive } \\
\text { deficits by decreasing } \\
\text { NMDA receptor } 1 \text { in the } \\
\text { CA2 and CA3 areas of } \\
\text { the hippocampus }\end{array}$ & Thailand & $\begin{array}{l}\text { (Piyabhan \& } \\
\text { Wetchateng, } \\
\text { 2014) }\end{array}$ \\
\hline Clinical & Standardized & $500 \mathrm{mg} /$ day & 4 weeks & $\begin{array}{c}\text { - Reduction of } \\
\text { psychopathology }\end{array}$ & India & $\begin{array}{c}\text { (Sarkar et al. } \\
\text { 2012) }\end{array}$ \\
\hline
\end{tabular}

\section{TOXICOLOGICAL EVALUATIONS}

The acute oral toxicity of $B$. monnieri extract was evaluated in female Sprague-Dawley rats that received a single dose of $5000 \mathrm{mg} / \mathrm{kg}$ and were monitored for toxic signs for 14 days. Chronic oral toxicity was evaluated in female and male rats that were treated daily with $B$. monnieri extract $(30,60$, 300 , or $1500 \mathrm{mg} / \mathrm{kg}$ for 270 days). Alterations of clinical signs were monitored. No signs of toxicity were observed with either acute or chronic exposure (Sireeratawong et al., 2016).

Allan et al. (2007), also performed a safety evaluation of a standardized extract of B. monnieri in male and female Sprague-Dawley rats. The results showed a median lethal dose of $2400 \mathrm{mg} / \mathrm{kg}$ (single oral administration) and mild lowering of body weight gain but no other signs of toxicity after 14 days of treatment with $500 \mathrm{mg} / \mathrm{kg}$. No evidence of toxicity was seen after 90 days of treatment with 85 , 210 , and $500 \mathrm{mg} / \mathrm{kg}$.
Rastogi et al. (2012b), orally treated male Wistar rats with bacoside for 12 weeks and observed no changes in body mass, liver function, or kidney function in animals that received $200 \mathrm{mg} / \mathrm{kg}$. However, hematological alterations were observed at doses of 50,100 , and $200 \mathrm{mg} / \mathrm{kg}$. At higher doses (400 and $800 \mathrm{mg} / \mathrm{kg}$ ), a slight decrease in body mass, decrease in albumin and protein content, and increase in plasma aspartate transaminase, alanine transaminase, and alkaline phosphatase were observed.

In humans who were treated with a therapeutic dose of B. monnieri for 12 weeks, some healthy elderly individuals exhibited gastrointestinal side effects (e.g., diarrhea, nausea, increase in stool frequency, and abdominal cramps), with no changes in hematological, biochemical, blood pressure, or electrocardiographic parameters (Calabrese et al., 2008, Peth-Nui et al., 2012, Piyabhan \& Wetchateng, 2014). 


\section{CONCLUSION}

Bacopa monnieri is a creeping perennial plant with a small stature that is distributed in India and other tropical regions. All parts of the plant are used for medicinal purposes. It is prepared as a decoction, infusion, juice, and powder, mainly in India. Its biologically active ingredients are concentrated in the stems and leaves. Its biological actions have been mainly attributed to its high content of bacosides, mainly bacoside-A. B. monnieri has been used to improve cognitive performance. Its preclinical biological actions include effects in Alzheimer's disease, Parkinson's disease, epilepsy, and schizophrenia. No acute toxicity was reported in a preclinical study of a $B$. monnieri. However, gastrointestinal side effects were reported in some healthy elderly individuals who received a therapeutic dose of $B$. monnieri. Although research on B. monnieri has been expanding, most studies have been preclinical evaluations of cellular mechanisms in the central nervous system. Further translational clinical research needs to be performed to evaluate the safety and efficacy of the plant in patients with Parkinson's disease, Alzheimer's disease, epilepsy, and schizophrenia. Controlled clinical trials also need to be conducted over long periods of time to affirm the beneficial biological activity of B. monnieri.

\section{ACKNOWLEDGMENTS}

The authors thank Michael Arends for proofreading the manuscript and to Raquel Aline Beltramin for the illustrations.

\section{FUNDING}

This work was supported by grants from Fundação de Apoio ao Desenvolvimento do Ensino, Ciência e Tecnologia do Estado de Mato Grosso do Sul (FUNDECT, Brazil, no. 59/300.046/2015) and Coordenadoria de Pós-Graduação de la Universidad Paranaense (UNIPAR).

\section{REFERENCES}

Aguiar S, Borowski T. 2013. Neuropharmacological review of the nootropic herb Bacopa monnieri. Rejuvenation Res 16: 313 - 326. https://doi.org/10.1089/rej.2013.1431

Ahn J, Ahn HS, Cheong JH, De la Peña I. 2016. Natural product-derived treatments for attentiondeficit/hiperactivity disorder: safety, efficacy, and therapeutic potential of combination therapy. Neural Plast 2016: Article ID 1320423. https://doi,org/10.1155/2016/1320423

Allan JJ, Damodaran A, Deshmukh NS, Goudar KS, Amit A. 2007. Safety evaluation of a standardized phytochemical composition extracted from Bacopa monnieri in Sprague-Dawley rats. Food Chem Toxicol 45: 1928 - 1937. https://doi.org/10.1016/j.fct.2007.04.010

Alzheimer's Association. 2016. 2016 Alzheimer's disease facts and figures. Alzheimer's Dement 12: 459 - 509. https://doi.org/10.1016/j.jalz.2016.03.001

Apostolova LG. 2016. Alzheimer disease. Continuum 22: 419 - 434. https://doi.org/10.1212/CON.0000000000000307

Armstrong MJ, Okun MS. 2020. Diagnosis and treatment of Parkinson sisease: a review. JAMA 323: 548 - 560. https://doi.org/10.1001/jama.2019.22360

Balestrino R, Schapira AHV. 2020. Parkinson disease. Eur J Neurol 27: 27 - 42. https://doi.org/10.1111/ene.14108

Bammidi SR, Volluri SS, Chippada SC, Avanigadda S, Vangalapati M. 2011. A review on pharmacological studies of Bacopa monnieri. J Chem Biol Phys Sci 1: 250 - 259.

Beghi E. 2020. The epidemiology of epilepsy. Neuroepidemiology 54: 185 - 191. https://doi.org/10.1159/000503831

Bhandari P, Kumar N, Singh B, Kaul VK. 2007. Cucurbitacins from Bacopa monnieri. Phytochemistry 68: 1248 1254. https://doi.org/10.1016/j.phytochem.2007.03.013

Bhattacharya SK, Bhattacharya A, Kumar A, Ghosal S. 2000. Antioxidant activity of Bacopa monniera in rat frontal cortex, striatum and hippocampus. Phytother Res 14: 174 - 179. https://doi,org/10.1002/(SICI)1099-1573(200005)14:3<174::AID-PTR624>3.0.CO;2-O

Calabrese C, Gregory WL, Leo M, Kraemer D, Bone K, Oken B. 2008. Effects of a standardized Bacopa monnieri extract on cognitive performance, anxiety, and depression in the elderly: a randomized, double-blind, placebo-controlled trial. J Altern Complement Med 14: 707 - 713.

https://doi,org/10.1089/acm.2008.0018

Boletín Latinoamericano y del Caribe de Plantas Medicinales y Aromáticas / 149 
Castelli V, Benedetti E, Antonosante A, Catanesi M, Pitari G, Ippoliti R, Cimini A, d'Angelo M. 2019. Neuronal cells rearrangement during aging and neurodegenerative disease: metabolism, oxidative stress and organelles dynamic. Front Mol Neurosci 12: 132. https://doi.org/10.3389/fnmol.2019.00132

Chaudhari KS, Tiwari NR, Tiwari RR, Sharma RS. 2007. Neurocognitive effect of nootropic drug Brahmi (Bacopa monnieri) in Alzheimer's disease. Ann Neurosci 24: 111 - 122. https://doi.org/10.1159/000475900

Cicero AFG, Fogacci F, Banach M. 2018. Botanicals and phytochemicals active on cognitive decline: the clinical evidence. Pharmacol Res 130: 204 - 212. https://doi.org/10.1016/j.phrs.2017.12.029

Das A, Shanker G, Nath C, Pal R, Singh S, Singh HK. 2002. A comparative study in rodents of standardized extracts of Bacopa monnieri and Ginkgo biloba. Pharmacol Biochem Behavior 73: 893 - 900. https://doi.org/10.1016/S0091-3057(02)00940-1

Deepak M, Amit A. 2004. The need for establishing identities of "bacoside A and B", the putative major bioactive saponins of Indian medicinal plant Bacopa monnieri. Phytomedicine 11: 264 - 268. https://doi.org/10.1078/0944-7113-00351

Deepak M, Sangli GK, Amit PC, Amit A. 2005. Quantitative determination of the major saponin mixture bacoside A in Bacopa monnieri by HPLC. Phytochem Anal 16: 24 - 29. https://doi.org/10.1002/pca.805

DeMaagd G, Philip A. 2015. Parkinson's disease and its management. part 1: disease entity, risk factors, pathophysiology, clinical presentation, and diagnosis. P T 40: $504-510$.

Dethe S, Deepak M, Agarwal A. 2016. Elucidation of molecular mechanism(s) of cognition enhancing activity of Bacomind $^{\circledR}$ : a standardized extract of Bacopa monnieri. Pharmacogn Magazine 12: 482 - 487. https://doi.org/10.4103/0973-1296.191464

Dhanasekaran M, Tharakan, B, Holcomb LA, Hitt AR, Young KA, Manyam BV. 2007. Neuroprotective mechanisms of ayurvedic antidementia botanical Bacopa monniera. Phytotherapy Res 21: 965 - 969. https://doi.org/10.1002/ptr.2195

Emilie A, François C, Geneviève B, Mayoura B, Jérémy J, Jaim L, Voa R, Pierre-Marie P, Farid, Boumediene F. 2019. Herbal medicine for epilepsy seizures in Asia, Africa and Latin America: A systematic review. J Ethnopharmacol 234: 119 - 153. https://doi.org/10.1016/j.jep.2018.12.049

Gentile G, La Cognata V, Cavallaro S. 2021. The contribution of CNVs to the most common aging-related neurodegenerative diseases. Aging Clin Exp Res 33: 1187 - 1195. https://doi.org/10.1007/s40520-020-01485-4

Gohil KJ, Patel JA. 2010. A review on Bacopa monniera: current research and future prospects. Int J Green Pharm 4: 1 - 9.

Hassler M. 2018. World plants: synonymic checklists of the vascular plants of the world. In: Roskov Y, Ower G, Orrell T, Nicolson D, Bailly N, Kirk PM, Bourgoin T, DeWalt RE, Decock W, Nieukerken E van, Zarucchi J, Penev L. Eds. Species 2000 \& ITIS catalogue of life. Naturalis, Leiden, The Netherlands. http://www.catalogueoflife.org/col/

Holcomb LA, Dhanasekaran M, Hitt AR, Young KA, Riggs M, Manyam BV. 2006. Bacopa monnieri extract reduces amyloid levels in PSAPP mice. J Alzheimers Dis 9: 243 - 251. https://doi.org/10.3233/JAD-2006-9303

Hosamani R, Krishna G, Muralidhara. 2016. Standardized Bacopa monnieri extract ameliorates acute paraquatinduced oxidative stress, and neurotoxicity in prepubertal mice brain. Nutr Neurosci 19: 434 - 446. https://doi.org/10.1179/1476830514Y.0000000149

Hosamani R, Muralidhara. 2009. Neuroprotective efficacy of Bacopa monnieri against rotenone induced oxidative stress and neurotoxicity in Drosophila melanogaster. Neurotoxicology 30: 977 - 985. https://doi.org/10.1016/j.neuro.2009.08.012

Hosamani R, Muralidhara. 2010. Prophylactic treatment with Bacopa monnieri leaf powder mitigates paraquatinduced oxidative perturbations and lethality in Drosophila melanogaster. Indian J Biochem Biophys 47: $75-82$.

Howes MJR, Houghton PJ. 2012. Ethnobotanical treatment strategies against Alzheimer's disease. Curr Alzheimer Res 9: 67 - 85. https://doi.org/10.2174/156720512799015046

Jadiya P, Khan A, Sammi SR, Kaur S, Mir SS, Nazir A. 2011. Anti-parkinsonian effects of Bacopa monnieri: insights from transgenic and pharmacological Caenorhabditis elegans models of Parkinson's disease. Biochem Biophys Res Commun 413: 605 - 610. https://doi.org/10.1016/j.bbrc.2011.09.010 
Jain PK, Das D. 2016. Pharmacognostic comparison of Bacopa monnieri, Cyperus rotundus, and Emblica officinalis. Innov J Ayurvedic Sci 4: 16 - 26.

Jansen RLM, Brogan B, Whitworth AJ, Okello EJ. 2014. Effects of five Ayurvedic herbs on locomotor behavior in a Drosophila melanogaster Parkinson's disease model. Phytother Res 28: 1789 - 1795. https://doi.org/10.1002/ptr.5199

Kean JD, Kaufman J, Lomas J, Goh A, White D, Simpson D, Scholey A, Singh H, Sarris J, Zangara A, Stough C. 2015. Randomized controlled trial investigating the effects of a special extract of Bacopa monnieri (CDRI 08) on hyperactivity and inattention in male children and adolescents: BACHI study protocol (ANZCTRN12612000827831). Nutrients 7: 9931 - 9945. https://doi.org/10.3390/nu7125507

Kean JD, Downey LA, Stough C. 2016. A systematic review of the ayurvedic medicinal herb Bacopa monnieri in child and adolescent populations. Complement Ther Med 29: 56 - 62. https://doi.org/10.1016/j.ctim.2016.09.002

Kean JD, Downey LA, Stough C. 2017. Systematic overview of Bacopa monnieri (L.) Wettst. Dominant polyherbal formulas in children and adolescents. Medicines 4: 86. https://doi.org/10.3390/medicines4040086

Kenedy DO. 2019. Phytochemicals for improving aspects of cognitive function and psychological state potentially relevant to sports performance. Sports Med 49: 39 - 58. https://doi.org/10.1007/s40279-018-1007-0

Khan R, Krishnakumar A, Paulose CS. 2008. Decreased glutamate receptor binding and NMDA R1 gene expression in hippocampus of pilocarpine-induced epileptic rats: neuroprotective role of Bacopa monnieri extract. Epilepsy Behav 12: 54 - 60. https://doi.org/10.1016/j.yebeh.2007.09.021

Khan ZU, Martin-Montañez E, Chris Muly E. 2013. Schizophrenia: causes and treatments. Curr Pharm Des 19: 6451 - 6461. https://doi.org/10.2174/1381612811319360006

Kongkeaw C, Dilokthornsakul P, Thanarangsarit P, Limpeanchob N, Scholfield CN. 2014. Meta-analysis of randomized controlled trials on cognitive effects of Bacopa monnieri extract. J Ethnopharmacol 151: 528 - 535. https://doi.org/10.1016/j.jep.2013.11.008

Krishna G, Hosamani R, Muralidhara. 2019. Bacopa monnieri supplements offset paraquat-induced behavioral phenotype and brain oxidative pathways in mice. Cent Nerv Syst Agents Med Chem 19: 57 - 66. https://doi.org/10.2174/1871524919666190115125900

Krishnakumar A, Abraham PM, Paul J, Paulose CS. 2009a. Down-regulation of cerebellar 5-HT2C receptors in pilocarpine-induced epilepsy in rats: Therapeutic role of Bacopa monnieri extract. J Neurol Sci 284: 124 128. https://doi.org/10.1016/j.jns.2009.04.032

Krishnakumar A, Nandhu MS, Paulose CS. 2009b. Upregulation of 5-HT2C receptors in hippocampus of pilocarpine-induced epileptic rats: Antagonism by Bacopa monnieri. Epilepsy Behav 16: 225 - 230. https://10.1016/j.yebeh.2009.07.031

Kumar A, Ekavali AS. 2015. A review on Alzheimer's disease pathophysiology and its management: an update. Pharmacol Rep 67: 195 - 203. https://doi.org/10.1016/j.pharep.2014.09.004

Kumar N, Abichandani LG, Thawani V, Gharpure KJ, Naidu MUR, Venkat Ramana, G. 2016. Efficacy of standardized extract of Bacopa monnieri (Bacognize ${ }^{\circledR}$ ) on cognitive functions of medical students: a sixweek, randomized placebo-controlled trial. Evid Based Complement Alternat Med 2016: 4103423. https://doi.org/10.1155/2016/4103423

Kwan P, Brodie MJ. 2001. Neuropsychological effects of epilepsy and antiepileptic drugs. Lancet 357: 216 - 222. https://doi.org/10.1016/S0140-6736(00)03600-X

Kwon HJ, Jung HY, Hahn KR, Kim W, Kim JW, Yoo DY, Yoo YS, Hwang IK, Kim DW. 2018. Bacopa monnieri extract improves novel object recognition, cell proliferation, neuroblast differentiation, brain-derived neurotrophic factor, and phosphorylation of cAMP response element-binding protein in the dentate gyrus. Lab Anim Res 34: 239 - 247. https://doi.org/10.5625/lar.2018.34.4.239

Lambert M, Karow A, Leucht S, Schimmelmann BG, Naber D. 2010. Remission in schizophrenia: validity, frequency, predictors, and patients' perspective 5 years later. Dialogues Clin Neurosci 12: 393 - 407. https://doi.org/10.31887/DCNS.2010.12.3/mlambert

Lang AE. 2009. When and how should treatment be started in Parkinson disease? Neurology 72: S39 - S43. https://doi.org/10.1212/WNL.0b013e318198e177

Le XT, Nguyet Pham HT, Van Nguyen T, Nguyen KM, Tanaka K, Fujiwara H, Matsumoto K. 2015. Protective effects of Bacopa monnieri on ischemia-induced cognitive deficits in mice: the possible contribution of 
bacopaside I and underlying mechanism. J Ethnopharmacol 164: 37 - 45.

https://doi.org/10.1016/j.jep.2015.01.041

Leucht S, Cipriani A, Spineli L, Mavridis D, Örey D, Richter F, Samara M, Barbui C, Engel RR, Geddes JR, Kissling W, Paul M, Lassing B, Salanti G, Davis JM. 2013. Comparative efficacy and tolerability of 15 antipsychotic drugs in schizophrenia: a multiple-treatments meta-analysis. Lancet 382: 951 - 962.

https://doi.org/10.1016/S0140-6736(13)60733-3

Limpeanchob N, Jaipan S, Rattanakaruna S, Phrompittayarat W, Ingkaninan K. 2008. Neuroprotective effect of Bacopa monnieri on beta-amyloid-induced cell death in primary cortical culture. J Ethnopharmacol 120: 112 - 117. https://doi.org/10.1016/j.jep.2008.07.039

Liu G, Slater N, Perkins A. 2017a. Epilepsy: treatment options. Am Fam Physician 96: 87 - 96.

Liu W, Ge T, Pan Z, Leng Y, Lv J, Li B. 2017b. The effects of herbal medicine on epilepsy. Oncotarget 8: 48385 48397. https://doi.org/10.18632/oncotarget.16801

Mallick M, Khan W, Parveen R, Ahmad S, Sadaf, Najm MZ, Ahmad I, Husain SA. 2017. Exploring the cytotoxic potential of triterpenoids-enriched fraction of Bacopa monnieri by implementing In vitro, In vivo, and In silico approaches. Pharmacogn Mag 13: 595 - 606. https://doi.org/10.4103/pm.pm_397_16

Mathew J, Gangadharan G, Kuruvilla KP, Paulose CS. 2011. Behavioral deficit and decreased GABA receptor functional regulation in the hippocampus of epileptic rats: effect of Bacopa monnieri. Neurochem Res 36: 7 - 16. https://doi.org/10.1007/s11064-010-0253-9

Mathew J, Paul J, Nandhu MS, Paulose CS. 2010a. Increased excitability and metabolism in pilocarpine induced epileptic rats: effect of Bacopa monnieri. Fitoterapia 81: 546 - 551. https://doi.org/10.1016/j.fitote.2010.01.017

Mathew J, Soman S, Sadanandan J, Paulose CS. 2010b. Decreased GABA receptor in the striatum and spatial recognition memory deficit in epileptic rats: effect of Bacopa monnieri and bacoside-A. J Ethnopharmacol 30: 255 - 261. https://doi.org/10.1016/j.jep.2010.04.043

Mathew M, Subramanian S. 2012. Evaluation of the anti-amyloidogenic potential of nootropic herbal extracts in vitro. Int J Pharmaceut Sci Res 3: 4276 - 4280.

McPhee GM, Downey LA, Noble A, Stough C. 2016. Cognitive training and Bacopa monnieri: evidence for a combined intervention to alleviate age associated cognitive decline. Med Hypotheses 95: 71 - 76. https://doi.org/10.1016/j.mehy.2016.09.002

Menon BR, Rathi MA, Thirumoorthi L, Gopalakrishnan VK. 2010. Potential effect of Bacopa monnieri on nitrobenzene induced liver damage in rats. Indian J Clin Biochem 25: 401 - 404. https://doi.org/10.1007/s12291-010-0048-4

Mhyre TR, Boyd JT, Hamill RW, Maguire-Zeiss KA. 2012. Parkinson's disease. Subcell Biochem 65: 389 - 455. https://doi.org/10.1007/978-94-007-5416-4_16

Morgan A, Stevens J. 2010. Does Bacopa monnieri improve memory performance in older persons? results of a randomized, placebo-controlled, double-blind trial. J Altern Complement Med 16: 753 - 759. https://doi.org/10.1089/acm.2009.0342

Mukherjee S, Dugad S, Bhandare R, Pawar N, Jagtap S, Pawar PK, Kulkarni O. 2011. Evaluation of comparative free-radical quenching potential of Brahmi (Bacopa monnieri) and Mandookparni (Centella asiatica). Ayu 32: 258 - 264. https://doi.org/10.4103/0974-8520.92549

Murman DL. 2015. The impact of age on cognition. Semin Hear 36: 111 - 121. https://doi.org/10.1055/s-0035-1555115

Nellore J, Pauline C, Amarnath K. 2013. Bacopa monnieri phytochemicals mediated synthesis of platinum nanoparticles and its neurorescue effect on 1-methyl 4-phenyl 1, 2, 3, 6 tetrahydropyridine-induced experimental parkinsonism in zebrafish. J Neurodegener Dis 2013: ID 972391. https://doi.org/10.1155/2013/972391

Olanow CW, Stern MB, Sethi K. 2009. The scientific and clinical basis for the treatment of Parkinson disease. Neurology 72: S1 - S136. https://doi.org/10.1212/WNL.0b013e3181a1d44c

Pandey R, Gupta S, Tandon S, Wolkenhauer O, Vera J, Gupta SK. 2010. Baccoside A suppresses epileptic-like seizure/convulsion in Caenorhabditis elegans. Seizure 19: 439 - 442. https://doi.org/10.1016/j.seizure.2010.06.005

Pase MP, Kean J, Sarris J, Neale C, Scholey AB, Stough C. 2012. The cognitive-enhancing effects of Bacopa 
monnieri: a systematic review of randomized, controlled human clinical trials. J Altern Complement Med 18: 647 - 652. https://doi.org/10.1089/acm.2011.0367

Paulose CS, Chathu F, Khan SR, Krishnakumar A. 2008. Neuroprotective role of Bacopa monnieri extract in epilepsy and effect of glucose supplementation during hypoxia: glutamate receptor gene expression. Neurochem Res 33: 1663 - 1671. https://doi.org/10.1007/s11064-007-9513-8

Peth-Nui T, Wattanathorn J, Muchimapura S, Tong-Un T, Piyavhatkul N, Rangseekajee P, Ingkaninan K, VittayaAreekul S. 2012. Effects of 12-week Bacopa monnieri consumption on attention, cognitive processing, working memory, and functions of both cholinergic and monoaminergic systems in healthy elderly volunteers. Evid Based Complement Alternat Med 2012: ID 606424.

https://doi.org/10.1155/2012/606424

Pham HTN, Phan SV, Tran HN, Phi XT, Le XT, Nguyen KM, Fujiwara H, Yonevama M, Ogita K, Yamaguchi T, Matsumoto, K. 2019. Bacopa monnieri (L.) ameliorates cognitive deficits caused in a trimethyltin-induced neurotoxicity model mice. Biol Pharm Bull 42: 1384 - 1393. https://doi.org/10.1248/bpb.b19-00288

Piyabhan P, Wetchateng T. 2014. Neuroprotective effects of Bacopa monnieri (Brahmi) on novel object recognition and NMDAR1 immunodensity in the prefrontal cortex, striatum and hippocampus of sub-chronic phencyclidine rat model of schizophrenia. J Med Assoc Thai 97: S50 - S55.

Piyabhan P, Wetchateng T. 2015. Bacopa monnieri (Brahmi) enhanced cognitive function and prevented cognitive impairment by increasing VGLUT2 immunodensity in prefrontal cortex of sub-chronic phencyclidine rat model of schizophrenia. J Med Assoc Thai 98: S7 - S15.

Piyabhan P, Wannasiri S, Naowaboot J. 2016. Bacopa monnieri (Brahmi) improved novel object recognition task and increased cerebral vesicular glutamate transporter type 3 in sub-chronic phencyclidine rat model of schizophrenia. Clin Exp Pharmacol Physiol 43: 1234 - 1242. https://doi.org/10.1111/1440-1681.12658

Poonam K, Singh GS. 2009. Ethnobotanical study of medicinal plants used by the Taungya community in Terai Arc Landscape, India. J Ethnopharmacol 123: 167 - 176. https://doi.org/10.1016/j.jep.2009.02.037

Rastogi M, Ojha RP, Devi BP, Aggarwal A, Agrawal A, Dubey GP. 2012a. Amelioration of age associated neuroinflammation on long term bacosides treatment. Neurochem Res 37: 869 - 874. https://doi.org/10.1007/s11064-011-0681-1

Rastogi M, Ojha RP, Prabu PC, Devi BP, Agrawal A, Dubey GP. 2012b. Prevention of age-associated neurodegeneration and promotion of healthy brain ageing in female Wistar rats by long term use of bacosides. Biogerontology 13: 183 - 195. https://doi.org/10.1007/s10522-011-9367-y

Roodenrys S, Booth D, Bulzomi S, Phipps A, Micallef C, Smoker J. 2002. Chronic effects of Brahmi (Bacopa monnieri) on human memory. Neuropsychopharmacol 27: 279 - 281. https://doi.org/10.1016/S0893-133X(01)00419-5

Sadhu A, Upadhyay P, Agrawal A, Ilango K, Karmakar D, Singh GPI, Dubey, GP. 2014. Management of cognitive determinants in senile dementia of Alzheimer's type: therapeutic potential of a novel polyherbal drug product. Clin Drug Investig 34: 857 - 869. https://doi.org/10.1007/s40261-014-0235-9

Saini N, Singh D, Sandhir R. 2012. Neuroprotective effects of Bacopa monnieri in experimental model of dementia. Neurochem Res 37: 1928 - 1937. https://doi.org/10.1007/s11064-012-0811-4

Saini N, Singh D, Sandhir R. 2019. Bacopa monnieri prevents colchicine-induced dementia by anti-inflammatory action. Metab Brain Dis 34: 505 - 518. https://doi.org/10.1007/s11011-018-0332-1

Saraf MK, Anand A, Prabhakar S. 2009. Scopolamine induced amnesia is reversed by Bacopa monnieri through participation of kinase-CREB pathway. Neurochem Res 35: 279 - 287. https://doi.org/10.1007/s11064-012-0811-4

Sarkar S, Mishra BR, Praharaj SK, Nizamie SH. 2012. Add-on effect of Brahmi in the management of schizophrenia. J Ayurveda Integr Med 3: 223 - 225.

Schrag A, Schott JM. 2006. Epidemiological, clinical, and genetic characteristics of early-onset parkinsonism. Lancet Neurol 5: 355 - 363. https://doi.org/10.1016/S1474-4422(06)70411-2

Shanmugasundaram ERB, Akbar GK Mohammed, Shanmugasundaram KR. 1991. Brahmighritham, an ayurvedic herbal formula for the control of epilepsy. J Ethnopharmacol 33: 269 - 276. https://doi.org/10.1016/0378-8741(91)90088-U

Sharma J, Gairola S, Gaur RD, Painuli RM, Siddiqi TO. 2013. Ethnomedicinal plants used for treating epilepsy by indigenous communities of sub-Himalayan region of Uttarakhand, India. J Ethnopharmacol 150: 353 - 
370._https://doi.org/10.1016/j.jep.2013.08.052

Shinomol GK, Muralidhara, Muchukunte M.S. Bharath. 2011. Exploring the role of "Brahmi" (Bacopa monnieri and Centella asiatica) in brain function and therapy. Recent Pat Endocr Metab Immune Drug Discov 5: 33 - 49. https://doi.org/10.2174/187221411794351833

Shinomol GK, Mythri RB, Srinivas Bharath MM, Muralidhara. 2012. Bacopa monnieri extract offsets rotenoneinduced cytotoxicity in dopaminergic cells and oxidative impairments in mice brain. Cell Mol Neurobiol. 32: 455 - 465. https://doi.org/10.1007/s10571-011-9776-0

Siddique YH, Mujtaba SF, Faisal M, Jyoti S, Naz F. 2014. The effect of Bacopa monnieri leaf extract on dietary supplementation in transgenic Drosophila model of Parkinson's disease. Eur J Integr Med 6: 571 - 580. https://doi.org/10.1016/j.eujim.2014.05.007

Silambarasan R, Ayyanar M. 2015. An ethnobotanical study of medicinal plants in Palamalai region of Eastern Ghats, India. J Ethnopharmacol 172: 162 - 178. https://doi.org/10.1016/j.jep.2015.05.046

Singh AG, Kumar A, Tewari DD. 2012. An ethnobotanical survey of medicinal plants used in Terai forest of western Nepal. J Ethnobiol Ethnomed 8: 1 - 14. https://doi.org/10.1186/1746-4269-8-19

Singh B, Pandey S, Verma R, Ansari JA, Mahdi AA. 2016. Comparative evaluation of extract of Bacopa monnieri and Mucuna pruriens as neuroprotectant in MPTP model of Parkinson's disease. Indian J Exp Biol 54: $758-766$.

Singh B, Pandey S, Yadav SK, Verma R, Singh SP, Mahdi AA. 2017. Role of ethanolic extract of Bacopa monnieri against 1-methyl-4-phenyl-1, 2, 3, 6-tetrahydropyridine (MPTP) induced mice model via inhibition of apoptotic pathways of dopaminergic neurons. Brain Res Bull 135: 120 - 128.

https://doi.org/10.1016/j.brainresbull.2017.10.007

Sireeratawong S, Jaijoy K, Khonsung P, Lertprasertsuk N, Ingkaninan K. 2016. Acute and chronic toxicities of Bacopa monnieri extract in Sprague-Dawley rats. Complement Altern Med 16: 1 - 10. https://doi.org/10.1186/s12906-016-1236-4

Sivaramakrishna C, Rao CV, Trimurtulu G, Vanisree M, Subbaraju GV. 2005. Triterpenoid glycosides from Bacopa monnieri. Phytochemistry 66: 2719 - 2728. https://doi.org/10.1016/j.phytochem.2005.09.016

Sokhi D, Diaz M, Ngugi A, Solomon T, Fevre E, Meyer AC. 2016. Epilepsy prevalence, treatment gap, and stigma in Western Kenya. Neurology 86: P1.272.

Srivastav P, Yadav RS. 2016. Efficacy of natural compounds in neurodegenerative disorders. Adv Neurobiol 12: 107 - 123. https://doi.org/10.1007/978-3-319-28383-8_7

Srivastav S, Fatima M, Mondal AC. 2018. Bacopa monnieri alleviates paraquat induced toxicity in Drosophila by inhibiting jnk mediated apoptosis through improved mitochondrial function and redox stabilization. Neurochem Int 121: 98 - 107. https://doi.org/10.1016/j.neuint.2018.10.001

Stafstrom CE, Carmant. L. 2015. Seizures and epilepsy: an overview for neuroscientists. Cold Spring Harb Perspect Med 5: a022426. https://doi.org/10.1101/cshperspect.a022426

Stough C, Lloyd J, Clarke J, Downey L, Hutchison C, Rodgers T, Nathan P. 2001. The chronic effects of an extract of Bacopa monniera (Brahmi) on cognitive function in healthy human subjects. Psychopharmacology 156: 481 - 484. https://doi.org/10.1007/s002130100815

Sukumaran NP, Amalraj A, Gopi S. 2019. Neuropharmacological and cognitive effects of Bacopa monnieri (L.) Wettest - A review on its mechanistic aspects. Complement Ther Med 44: 68 - 82. https://doi.org/10.1016/j.ctim.2019.03.016

Tandon R, Belmaker RH, Gattaz WF, Lopez-Ibor Jr JJ, Okasha A, Singh B, Stein DJ, Olie Jp, Fleischhacker WW, Moeller HJ. 2008. World psychiatric association pharmacopsychiatry section statement on comparative effectiveness of antipsychotics in the treatment of schizophrenia. Schizophr Res 100: 20 - 38. https://doi.org/10.1016/j.schres.2007.11.033

Thijs RD, Surges R, O'Brien TJ, Sander JW. 2019. Epilepsy in adults. Lancet 393: 689 - 701. https://doi.org/10.1016/S0140-6736(18)32596-0

Thomas RB, Joy S, Ajayan MS, Paulose CS. 2013. Neuroprotective potential of Bacopa monnieri and bacoside A against dopamine receptor dysfunction in the cerebral cortex of neonatal hypoglycaemic rats. Cell Mol Neurobiol 33: 1065 - 1074. https://doi.org/10.1007/s10571-013-9973-0

Uabundit N, Wattanathorn J, Mucimapura S, Ingkaninan K. 2010. Cognitive enhancement and neuroprotective effects of Bacopa monnieri in Alzheimer's disease model. J Ethnopharmacol 127: 26 - 31.

Boletín Latinoamericano y del Caribe de Plantas Medicinales y Aromáticas / 154 
https://doi.org/10.1016/j.jep.2009.09.056

Valenzuela CF, Puglia MP, Zucca S. 2011. Focus on neurotransmitter systems. Alcohol Res Health 34: 106 - 120.

Vannorsdall TD, Schretlen DJ. 2019. Late-onset schizophrenia. In: Handbooks in neuropsychology of aging and dementia. Springer, Germany. https://doi.org/10.1007/978-3-319-93497-6_42

WHO (World Health Organization). 2005. Atlas epilepsy care in the world. Geneva, Switzerland.

WHO (World Health Organization). 2011. Global health and aging. Geneva, Switzerland.

Witter S, Witter R, Vilu R, Samoson A. 2018. Medical plants and nutraceuticals for amyloid- $\beta$ fibrillation inhibition. J Alzheimers Dis Rep 2: 239 - 252. https://doi.org/10.3233/ADR-180066

Zhou Y, Shen YH, Zhang C, Su J, Liu RH, Zhang WD. 2007. Triterpene saponins from Bacopa monnieri and their antidepressant effects in two mice models. J Nat Prod 70: 652 - 655. https://doi.org/10.1021/np060470s 